Eo miper as en yeppesifma dur gyjpetin patgan

6.5 6. 2 (arb) (s) 


\section{Devotion and Dissent in Late-Medieval Illuminated World Chronicles \\ Nina Rowe}

Detail of Nebuchadnezzar's

Idol, from a World Chronicle, Bavaria, 1402 (plate I7).

DOI:

10.1111/1467-8365.12288

Art History| ISSN 0141-6790

41 | I| February 2018 | pages 12-41
Courtiers decked out in the fashions of the mid-fourteenth century kneel before a golden finial raised up on a slender colonnette (plate 1). Pictured are a mature man and a youth, both dressed in form-fitting surcoats and tight leggings. They bracket a woman whose garb marks her as one of the elite of the German region. She wears a frilled headscarf with multiple ruffled rows and a similarly fluffy collar, and her long fur-lined robe falls in tangles, down to her bended knee, finally enfolding a dainty foot. The elevated finial venerated by the crowd, for its part, follows conventions for ornament adorning northern European architecture from the thirteenth century on. A central pointed lobe is surrounded by out-curving sculpted leaves, the lushness of the form enhanced through its installation upon a disk, further encircled by foliage. The multi-part finial rests upon a simple capital, down from which extends a narrow column, embellished at the base with further undulating leaves. The whole structure is gilt, and strong black lines articulate the work's intricacies.

The image of fashionable people worshipping a finial is an illumination found in a profusely adorned Weltchronik or World Chronicle manuscript, produced in southern Germany or Austria around 1370, and now housed in Munich (Bayerische Staatsbibliothek Cgm 5). ${ }^{1}$ It accompanies an episode from the biblical story of Daniel at the Babylonian court where, after King Nebuchadnezzar has had a dream of a sculpture in four materials and is told that it portends the passing of his reign, the monarch erects an idol as a sign of his authority and entreats his subjects to fall to their knees before it. The veneration of Nebuchadnezzar's idol is not unusual in pictorial sequences illustrating the Daniel story in illuminated Weltchroniken - a genre that was favoured by upper-crust burghers and lower nobles in the Germanspeaking lands of the late Middle Ages. But the manner of illustrating the scene in this manuscript is noteworthy because of its overt depiction of Nebuchadezzar's idol as an ornamental element drawn directly from gothic architectural vocabulary and its presentation of the idol's worshippers as devotees dressed in the fashions of the day.

The illuminator's act of rendering idol worship in the biblical past while invoking sartorial and architectural modes of the contemporary moment invites speculation about the artist's goals and the manner in which his message was received. The Munich manuscript is a lavish book with 223 parchment folios, adorned with some 330 tempera illuminations. It was made in an urban workshop, likely in one of the leading centres for manuscript production in the late fourteenth century in the regions of Bavaria and Austria - Regensburg, Nuremberg, Augsburg, or Vienna. ${ }^{2}$ These cities were sites of expansive new building projects where ecclesiastical structures were 


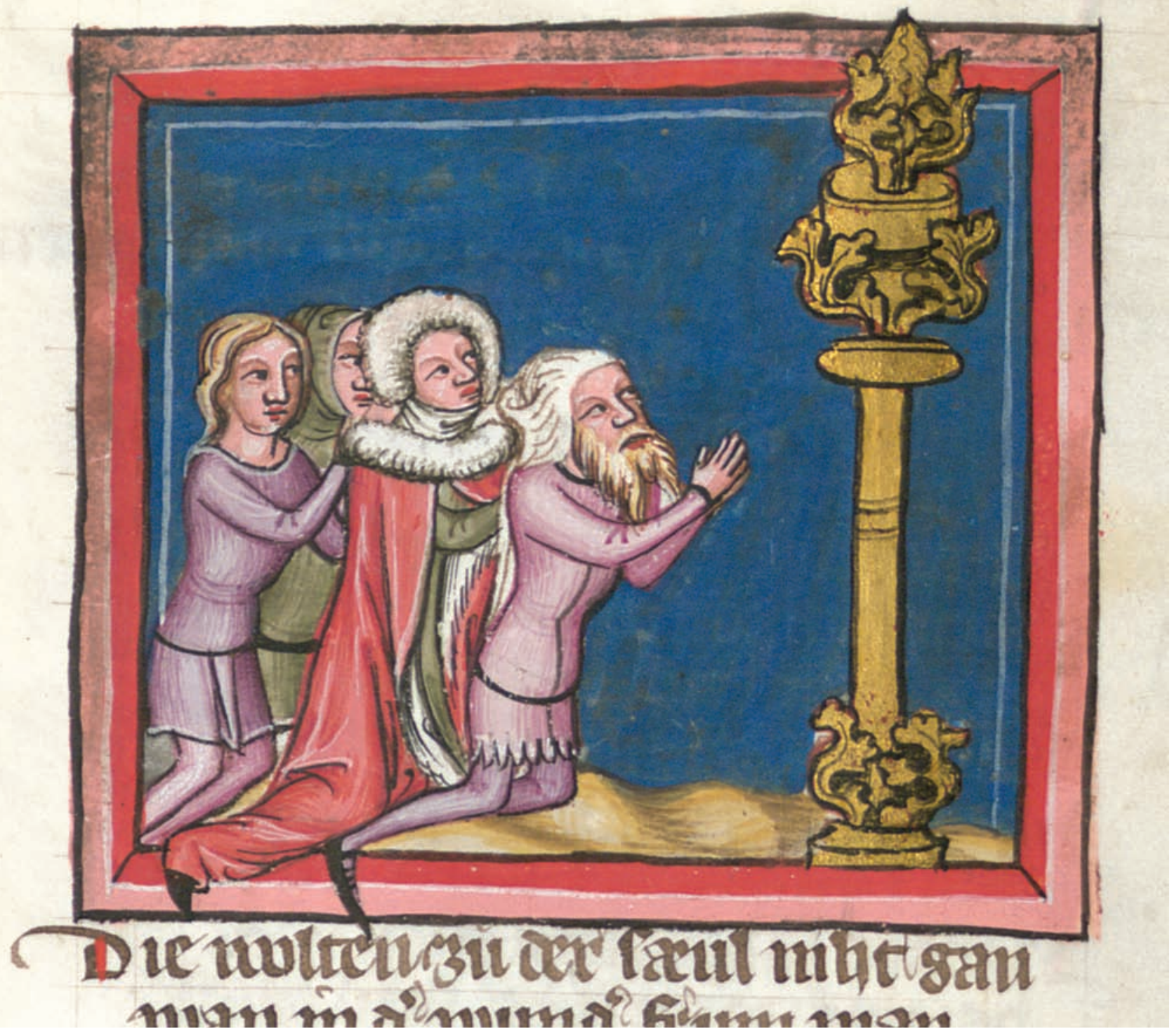

\begin{abstract}
I Veneration of
Nebuchadnezzar's Idol, from a World Chronicle, BavariaAustria, c. 1370. Munich:

Bayerische Staatsbibliothek (Cgm 5, fol. 170v). Photo:

Bayerische Staatsbibliothek.
\end{abstract}

littered with finials of the kind depicted in the scene of Nebuchadnezzar's idol in the Munich manuscript, not to mention the other elements of architectural adornment found on city buildings in this era - the crockets, gables, colonnettes, pointed arches, and soaring vaults that are hallmarks of the building style called 'modern' in its day and known now as gothic. ${ }^{3}$ The thriving urban centres of southern Germany and Austria also were arenas for devotional practices focused on sculpted images of Christ, the Virgin, and the saints. Often such images were striking in their renderings of sweet maternal intimacy or agonized visceral suffering, and scholars recently have explored and sometimes celebrated the ways in which veneration of sculpted works could manifest what is taken to be an earnest and creative exercise of piety. ${ }^{4}$ But the era in which sculpted and painted figures became central to Christian worship, the age of lavishly ornamented gothic cathedrals, and the period when illuminated Weltchroniken were most widely produced, was also an historical moment that witnessed biting critiques of the ecclesiastical promotion of image-centred devotion. For in the second half of the fourteenth century, on through into the fifteenth century, there were vast populations across the Holy Roman Empire of dissenters typically known 
as Waldensians, who scorned what they deemed to be excessive expenditures on church construction and who denounced ecclesiastical entreaties that the faithful get on their knees before images. The Munich codex was made in a time and place where dissidents vocally and publicly expressed scorn for church practice, and this manuscript's image of idol worship at Nebuchadnezzar's court, in turn, seems to ridicule or at least betray hesitation about contemporary practices.

In this article, I seek to demonstrate the ways in which the Munich World Chronicle introduced at the outset of my discussion draws direct connections between the idolatry of the biblical past and Christian devotion in the late medieval present, and I extend the inquiry to try to discern similar expressions of unease with mainstream Christian practices in two related Weltchronik manuscripts, one created around 1360, now in Regensburg (Fürst Thurn und Taxis Hofbibliothek, Ms. Perg. III) ${ }^{5}$ and the other dated to 1402, now in New York (New York Public Library, Spencer Ms. 38). ${ }^{6}$ These three codices are representative witnesses of the illuminated Weltchronik genre, a manuscript type that was in vogue among high estate city dwellers between roughly 1330 and 1430, especially in the southern German and Austrian orbit. Although we lack concrete evidence about the production and reception of illuminated World Chronicle manuscripts, the foundational survey study of this class of book reveals general patterns. On the whole, it appears that the manuscripts were created in urban workshops and directions and rubrics for illustrations indicate a division of labour between scribes and illuminators. ${ }^{7}$ Moreover, colophons, dedication images, and heraldry found in ten of the fifty-six surviving illuminated Weltchroniken lead to the conclusion that the manuscripts were prized by members of the lower nobility, patricians, and high ranking burghers. ${ }^{8}$

What is striking about these works is that none seems to have been made for imperial or princely courts. That is, illuminated Weltchroniken constitute a book type that was enjoyed by reader-viewers who certainly were elite, but who lay outside the most powerful political and ecclesiastical ranks. Illuminated World Chronicles thus can complicate the stories we tell about art, society, and religious belief in the late Middle Ages. For medieval art historians are often constrained to consider the tastes and experience of those at the pinnacle of society, since on the whole it was artworks made for emperors, princes, queens, bishops, and the like that were prized and survived over the centuries. Illuminated chronicles, such as those in Regensburg, Munich, and New York, on the other hand, were made for wealthy owners, but ones who circulated in the expanding cities of the era. Such book collectors likely resided in urban abodes at the heart of mercantile and civic life. In their day-to-day activities they would brush shoulders with other patricians and high status burghers, craftspeople, foreigners, the poor, and all manner of urban-dweller. As possessions of patrons entrenched in heterogeneous city life, illuminated Weltchroniken were cultural productions tethered to the strains and aspirations of urban existence to a degree not found in works made for imperial and princely circles.

The World Chronicle manuscripts in Regensburg, Munich, and New York that I examine in this article form a cluster that coheres iconographically in the sections telling the story of King Nebuchadnezzar and Daniel. I select these works from a suite of eleven surviving illuminated Weltchroniken which feature extended narratives of Daniel at the Babylonian court. ${ }^{9}$ The approach to rendering of Nebuchadezzar's idol is a key element uniting the group. In most illuminated Weltchroniken, Nebuchadnezzar's idol is depicted as a sturdy pillar, evoking the columns of Roman antiquity. Illuminations of the Babylonian idol in the Regensburg and Munich manuscripts, however, appear as spindly colonnettes of the modern or gothic style, thus referencing contemporary architecture, as in the image discussed already (see plate 1). 
The New York manuscript's Nebuchadnezzar scenes feature an idol/pillar that does not look gothic in style, but other iconographic elements, to be discussed below, bind it to the Regensburg and Munich manuscripts, demonstrating that it stands as a later exemplar of trends discerned in the previous works.

In this inquiry, after first introducing the illuminated Weltchronik genre and reviewing scholarship, I lay the foundation of my analysis by considering the world in which these illustrated books circulated, imagining Regensburg - or a city like it - as the locale for the creation and reception of the manuscripts and going on to discuss particulars of the apparel favoured by fashionable ladies in late medieval German and Austrian cities. I then aim to show that the Regensburg, Munich, and New York manuscripts exhibit preoccupations with the theme of idolatry through their handling of iconographic themes and captions. This preoccupation, I contend, finds parallels in more amplified form in expressions of disgust over ecclesiastical practices voiced by populations deemed to be Waldensian heretics. These dissidents resided in the same cities as the makers and users of illuminated Weltchroniken, and though the manuscripts by no means articulate what might be termed a Waldensian position, I suggest that they question dominant devotional practices in a manner parallel to Waldensian rebukes of the church. I seek evidence of this questioning in images and texts telling the story of Daniel at the court of Nebuchadnezzar in the Weltchroniken. While the theme of idolatry emerges throughout the manuscripts under consideration, this portion of the Weltchronik offers a tight narrative where an image sent by God - the dream of Nebuchadnezzar - is juxtaposed to a patently illicit idol. In what follows, analysis of image and text in the Regensburg, Munich, and New York manuscripts shows that over the course of roughly the half century when Waldensians were vocally denouncing the church as idolatrous, illuminated World Chronicles could express their own doubts about the pious acts of the day. Ultimately, the aim of this inquiry is to enrich the art-historical picture of the late Middle Ages. While recent work has revealed the variety and texture of Christian devotion in the German realm, the voices of sceptics have until now largely been silenced in art-historical discourse.

\section{Genre and Scholarship}

As mentioned already, illuminated Weltchroniken were produced in great numbers in the expanding cities of southern Germany and Austria in the fourteenth and early fifteenth centuries. ${ }^{10}$ The texts are in Middle High German couplets and recount world history from Creation to the present moment, shifting seamlessly between episodes from the biblical and the profane past - from tales of the Exodus or King David's reign to the Battle of Troy, or from the story of Job to the myth of the Minotaur, culminating with accounts of the ancient Roman emperors and rulers of the current age, including Charlemagne and Emperor Frederick II. The Vulgate and Peter Comestor's Historia scholastica (c. 1173) provide the foundation for the text, but manuscripts can incorporate long passages on histories that vary in their focus depending on the purchasers' tastes the range includes Konrad von Würzburg's (d. 1287) versified account of the Trojanerkrieg as well as spiritual works like Bruder Philipp's (d. 1345) vernacular verse anecdotes on the Virgin and Christ, the Marienleben. The author typically associated with the Weltchronik genre is Rudolf von Ems (d. 1254), a member of the Austrian ministerial estate, writing at the court of King Conrad IV. But of the twenty-two illuminated World Chronicle manuscripts dated to the genre's heyday in Bavaria and Austria, c. 1330 to 1430, which are now intact (rather than fragmentary), most feature large portions of text by two further authors - one who has come to be known as the Christherre-Poet, because of his text's opening invocation to Christ, and Jans der Enikel (also known as Jans Enikel 
or Jans von Wien; fl. 1271-1302), a Viennese patrician. ${ }^{11}$ Jans der Enikel is the only Weltchronik author to cover the history of Daniel at Nebuchadnezzar's court in depth (ll. 16933-18164), ${ }^{12}$ so it is his text that is most relevant to the present analysis. ${ }^{13}$

Despite the profusion of abundantly illuminated Weltchroniken that exist, this genre has been the subject of limited art-historical scholarship. Foundational studies give an introductory assessment of stylistic trends and iconographic types, ${ }^{14}$ and Jörn-Uwe Günther's catalogue of all the known illuminated Weltchroniken up to the early 1990s is a key reference. ${ }^{15}$ A dissertation argues that illuminations in the Munich manuscript examined in this article and another illuminated World Chronicle evince an embrace of luxury in the wake of the Black Death, and a further recent study considers the experiences of reader-viewers. ${ }^{16}$ But beyond those inquiries, the dynamics of word and picture on the manuscript page and their social meanings for Weltchronik audiences have, until now, been little considered. ${ }^{17}$

In analysing Christian anxieties about idolatry in relation to the technicalities of image form and reception, I insert myself into an established research conversation and seek to advance the inquiry through focused investigation of one genre in a circumscribed time and place. In his sweeping study, The Gothic Idol, Michael Camille first drew attention to the theme of idolatry in thirteenth- and fourteenth-century art and perceived its preponderance to be a response to misgivings over the expanding visual realm of the church at the time and the increased centrality of images in western Christian devotion. ${ }^{18}$ Discussing close to two hundred works, Camille's inquiry is broad and introduces scores of milieus, both pictorial and textual, in which notions of idolatry were used to advance ecclesiological, political, and social agendas. The image of the idol, for instance, could serve to establish the contours of licit and illicit devotion, to denigrate Muslims, Jews, and other non-Christians, or to position the medieval present in relation to the Roman imperial past, among other uses. While Camille examines media including sculpture and stained glass, most of his visual evidence is drawn from high medieval French and English manuscript illuminations, with an emphasis on iconography more than on the function of the book in the particular social world of the reader-viewer.

Beate Fricke, in contrast, grounds her Fallen Idols - Risen Saints in the specific temporal and geographic setting of the ninth century in southern and central France. ${ }^{19}$ Focusing discussion around the reliquary of Sainte-Foy at Conques, but also considering sculptures of the crucifixion and the Virgin and Child, Fricke probes the relationship between the introduction of monumental sculpture into Christian devotion and contemporary conceptions of idolatry at a critical moment in the history of the image in the church. Key for her are visual and material elements of the sculptures in question, particularly their metallic and gem-encrusted forms. Fricke's analysis of the intersection of notions of idolatry with conditions of image production and reception as well as with aesthetics serves as a model for my own investigations of idolatry in illuminated Weltchroniken.

Finally, Amy Knight Powell sets forth a bold argument in which she encourages art historians to look with scepticism on both medieval and recent accounts of late medieval iconophilia and credulousness in image-centred devotion. ${ }^{20}$ Powell's Depositions book touches on phenomena ranging from late medieval Easter liturgies, to painting conventions in fifteenth-century Flanders, to contemporary museum practices, to surrealist and minimalist art. But the through-line relevant to my own investigation is Powell's contention that late medieval lay people often were uneasy about imagecentred devotion and that both the Good Friday practice of burying the sculpted body of Christ and paintings of the Deposition, from Rogier van der Weyden's celebrated example (c. 1435) through later reworkings, articulated a drive to allegorize the image's 
lack of potency 'as such' and to 'have done' with images. ${ }^{21}$ Powell's search for arthistorical evidence of lay critique of church practices runs parallel to my own interests in investigating illuminated Weltchroniken, as does her recognition of the relevance of the iconophobic positions of putatively 'heretical' populations. ${ }^{22}$

In my own inquiry, I aim to enrich the discourse inaugurated a quarter of a century ago by Michael Camille. Camille was one of a cluster of art historians who recognized that medievalists need not always tell the story of the highest echelons of society and that by attending closely to the forms and materials even of luxury or monumental artworks one might still hear echoes of the voices of society's middle or lower ranks. The three illuminated Weltchroniken I examine in this article certainly were acquired by well-heeled customers in late medieval Bavaria or Austria. But they were not made for those in imperial or princely circles, and so within them I hope to discern the concerns of lay people living in the thick of expanding urban arenas, rather than those residing in the remote courts of the day. Like Fricke's, my study is bound geographically and temporally, focusing on works all created in urban centres in the southern part of the Holy Roman Empire between roughly 1360 and 1400, allowing me to consider manuscripts made and used in the region in relation to the critiques of the church launched by Waldensian heretics, who also thrived in this time and place. Finally, like Powell, I seek traces within the visual particularities of images and strive to discern in painted forms evidence of broader critical thought.

\section{Manuscripts in the City}

The Weltchronik manuscripts that are the focus of this investigation all were made and likely consumed in urban centres of southern Germany and Austria. Textual and stylistic clues found in the works hint at sites of production and original ownership,

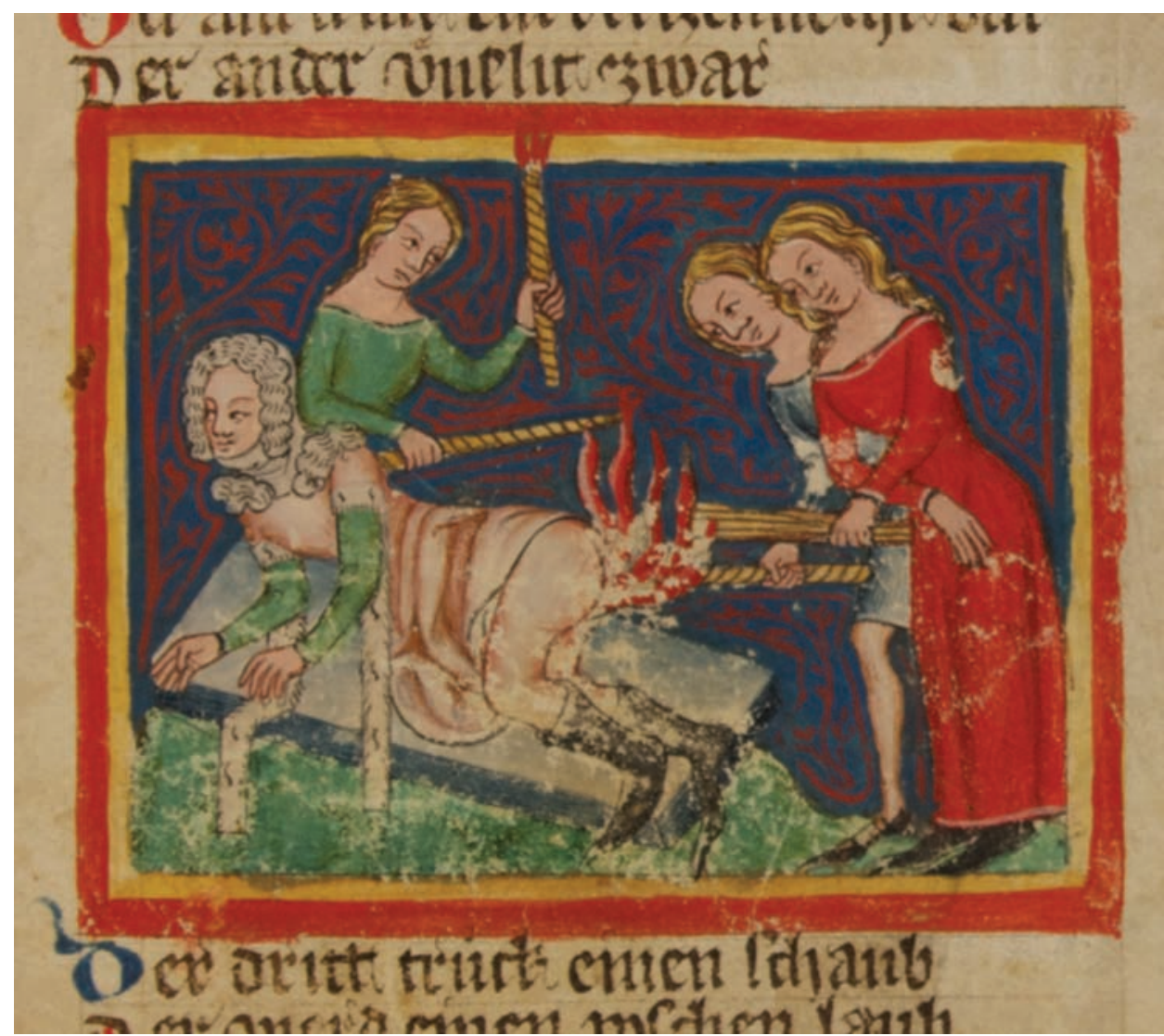

2 Romans Draw Fire from between the Legs of a Woman, from a World Chronicle, Bavaria, c. 1360. Regensburg: Fürst Thurn und Taxis Hofbibliothek (Ms. Perg. III, fol. 137r). Photo: Fürst Thurn und Taxis Hofbibliothek. 
3 Delilah Cuts Samson's Hair, from a World Chronicle, Bavaria-Austria, c. 1370. Munich: Bayerische

Staatsbibliothek (Cgm 5, fol. 148v). Photo: Bayerische Staatsbibliothek.

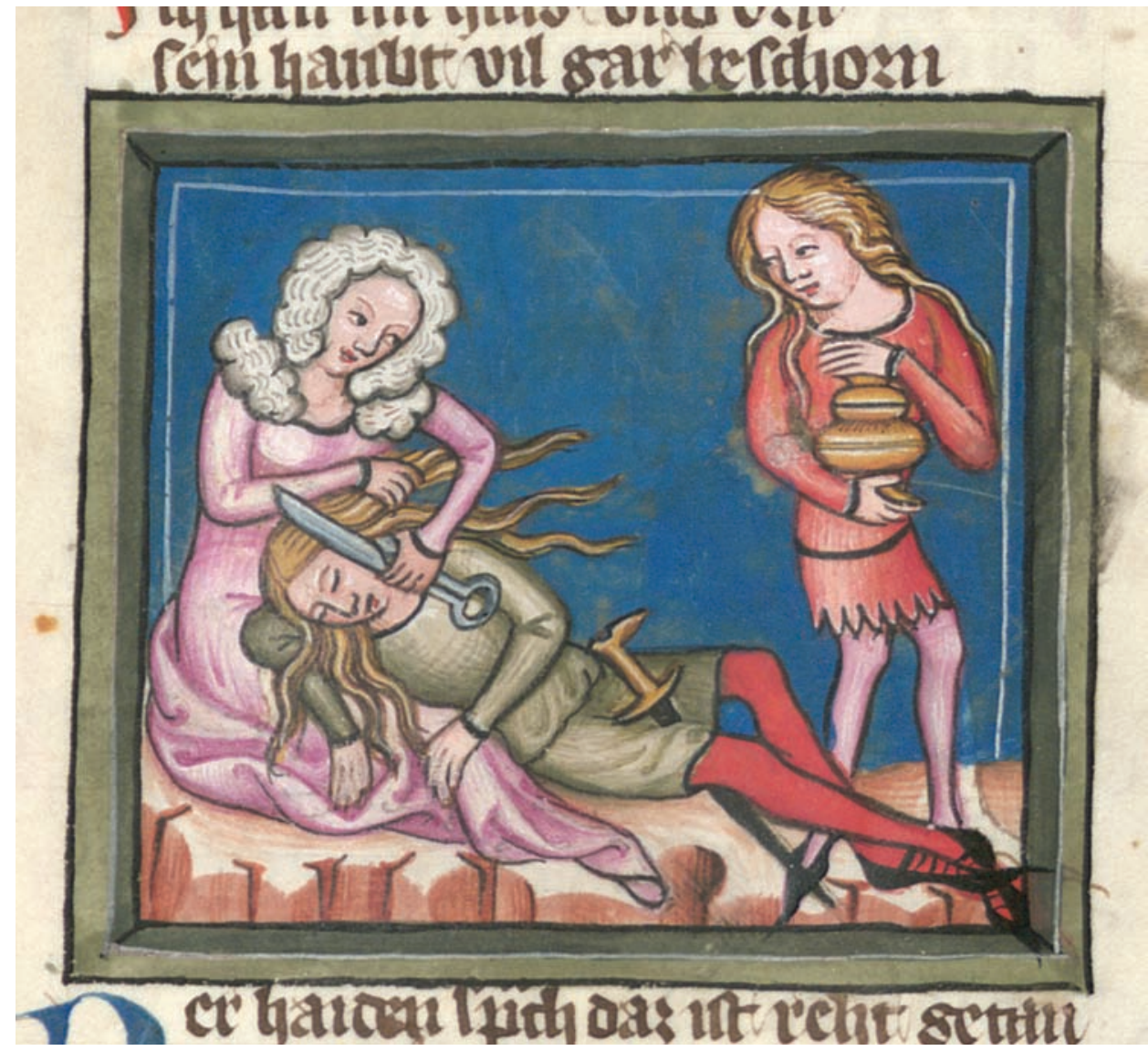

and the modish garb worn by select female characters in the illuminated histories links the ancient and biblical past depicted in the books to lived experience in the late medieval present. The environment in which Weltchroniken circulated included streets lined with urban palaces, encircling city centres dominated by cathedrals and other large-scale ecclesiastical buildings which were, in turn, encrusted with finials and colonnettes of the kind that stand in for idolatry in the Munich manuscript introduced at the opening of this article. Examination of three illuminated World Chronicles within their urban milieus evokes the terrain in which reader-viewers could contemplate biblical history while reflecting on the practices of the current moment.

The Regensburg, Munich, and New York codices are all richly adorned with roughly 250 to 330 illuminations, and represent the high-end of workmanship. The Regensburg and Munich manuscripts are made in the traditional medium of tempera on parchment, while the New York manuscript is in a more avant-garde mode, being of paper and painted with washes. The exemplar now in Regensburg is the earliest in the series, localized to Bavaria, 1360. A mid-fifteenth-century note in this codex identifies the book as the possession of a government official (a Landschreiber) named Hans Putzer from Burghausen in upper Bavaria (today at the Austrian border), an indication of the elite, though not always noble, circles that made up the audience for illuminated Weltchroniken. ${ }^{23}$ The Munich World Chronicle, for its part, dates to around 1370 and scholars have placed its production perhaps in Regensburg, or in a centre further east, owing to iconographic affinities to an Austrian manuscript now in Linz. ${ }^{24}$ Finally, the New York Public Library manuscript falls at the end of the sequence, with a colophon dating it firmly to 1402 and stylistic aspects indicating its production in and around the Danube in Bavaria. Over the four decades in which the Regensburg, 
4 Alexander in a Diving Bell, from a World Chronicle, Bavaria, 1402. New York: Spencer Collection, New York Public Library (Ms. 38 , fol. 332r). Photo: Spencer Collection, The New York Public Library, Astor, Lenox, and Tilden Foundations.

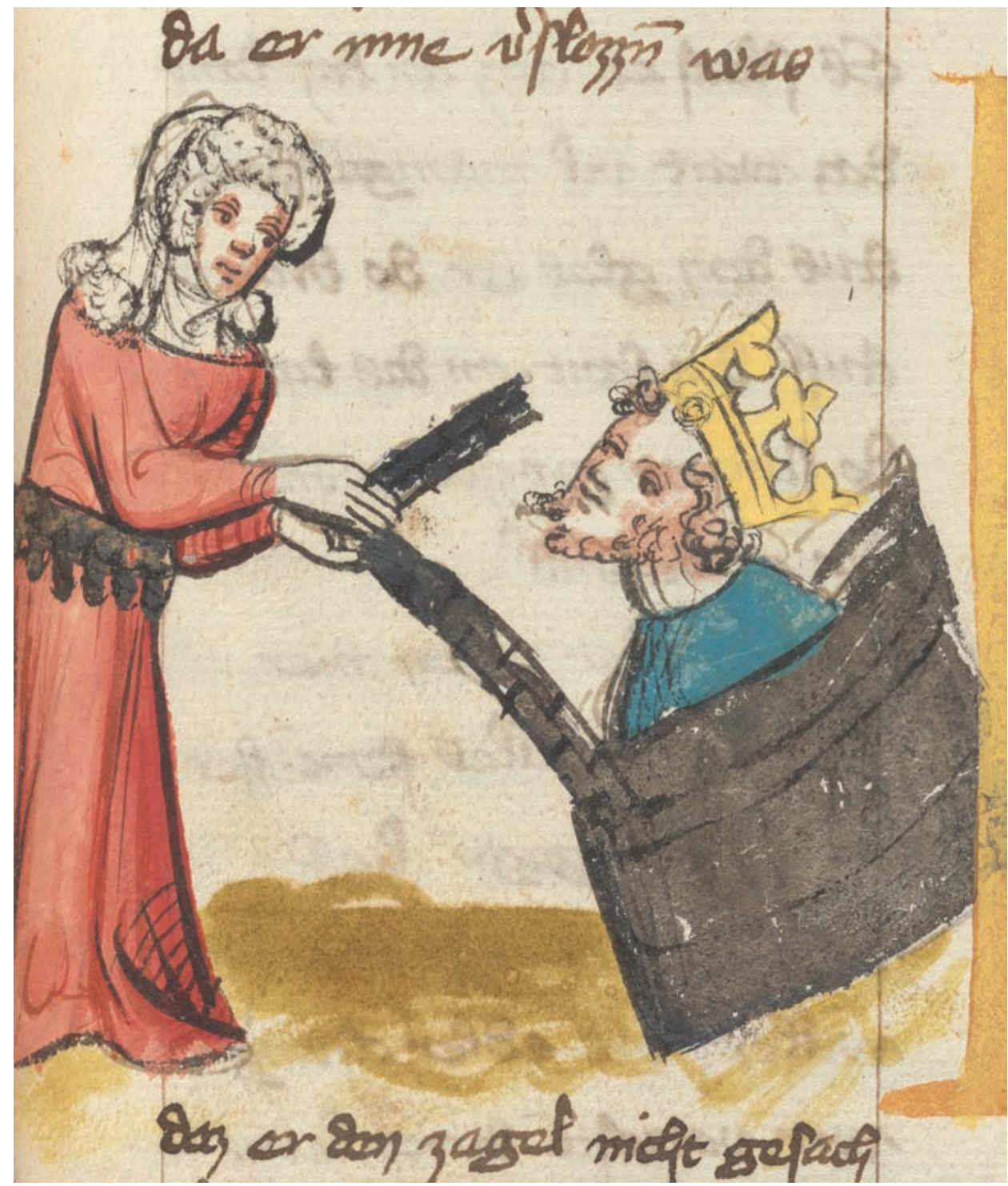

Munich, and New York manuscripts were created, illuminators of Weltchroniken codified and modified iconographically distinctive illuminated cycles. In the twentytwo relatively complete, illuminated Weltchronik codices from Bavaria or Austria, formulas for the rendering of biblical, ancient, and mythological history recur. But the trio of the Regensburg, Munich, and New York manuscripts exhibit a shared interest in clothing characters from the past following the trends of the late medieval present and in inserting pictorial sequences that explore the practices of idolatry.

In the three manuscripts under investigation, a distinctive costume, adopted from the fashions of the day, is used to identify naughty or otherwise dangerous women. This attire appears in the Regensburg manuscript some twenty times, in scenes ranging from the biblical episode with the blasphemous Babylonian feast and the 'writing on the wall' (fol. 100r), to tales from ancient Rome, such as one where men draw fire from between the legs of a woman who betrayed Virgil (fol. 137r, plate 2). The degenerate ladies of these scenes wear pink gowns, tightly fitted at the bust. But what most sets them apart is the fluffy white trim that encircles their faces and snakes around their necklines. These frilled, fur-like ornaments are known as Kruseler and they were the height of fashion in the Holy Roman Empire in the mid- to 
5 Elizabeth of Pomerania and a Female Attendant, south façade, Marienkirche, Mühlhausen, Germany, 136280. Photo: Foto Marburg/Art Resource, NY. late fourteenth century. ${ }^{25}$ This is the same garb evident in the image with which I opened this argument (see plate 1), and elsewhere in the Munich manuscript, devious women wearing Kruseler abound, surfacing some thirty-three times. Potiphar's wife is dressed in this manner as she paws Joseph (fol. 55v). So too is Delilah as she shears Samson's hair (fol. 148v; plate 3), as are Juno and Venus in the scene of the Judgment of Paris (fol. 154v). And in the Regensburg, Munich, and New York manuscripts alike, in the scene from the Legend of Alexander where the king submerges himself in a glass diving bell and his beloved entrusted with holding the chain releases it, that treacherous Frau wears Kruseler (Regensburg, fol. 108v; Munich, fol. 179v, and New York, fol. 332r, plate 4). ${ }^{26}$

The distinctive garb worn by particularly sexy or dangerous women in the Regensburg, Munich and, to a lesser degree, the New York manuscripts was the product of a radical shift in fashions in the German domain in the mid-fourteenth century. Up to about 1325, clothing for men and women in this region tended to be loose fitting and long, with wide robes, sometimes richly ornamented, but effectively shrouding the body. Around 1350, however, new modes were developed, in part facilitated by the development of the button, with short coats and tight leggings for men, and form-fitting bodices for women. ${ }^{27}$ In tandem, fashionable ladies started to favour daring décolletage, often enhanced by ruffles at the collar, with a further frilled veil framing the face - Kruseler. And it is not only ladies depicted in Weltchronik manuscripts who wear Kruseler. This form of ruffled headscarf, sometimes augmented by a fluffy collar, appears in representations of powerful women throughout the Holy Roman Empire. Of many possible examples, the get-up is found, for instance, on the sculpted figures of Elizabeth of Pomerania and a female attendant who, along with Elizabeth's husband Emperor Charles IV and a male courtier, are depicted on the balcony at the south façade of the Marienkirche in Mühlhausen in Thuringia (1362-80) (plate 5). ${ }^{28}$ And Elizabeth von Hohenzollern-Nürnberg, wife of Kurfürst Ruprecht III von der Pfalz, wears the same in the effigy on her early fifteenth-century tomb in Heidelberg's Heiliggeistkirche. ${ }^{29}$ Among the profuse sumptuary ordinances issued in the German realm in the fourteenth and fifteenth centuries, Kruseler regularly are singled out, with efforts to keep their lavishness in check. Typically such codes

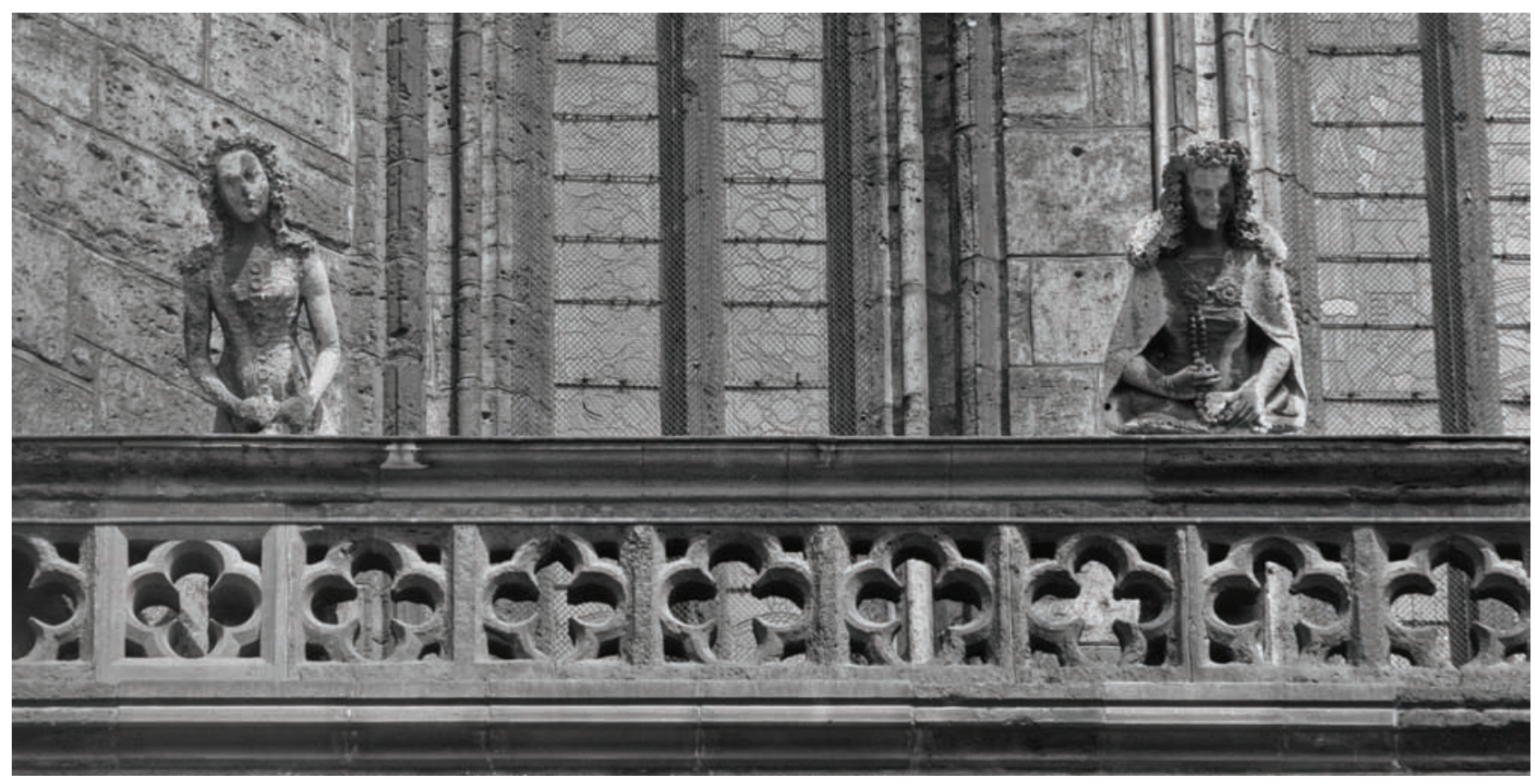


limit the number of rows of puckers (vach) allowed, the standard being four rows. Some southern German cities, however, could allow up to twenty rows of folds, as is evident in a city regulation from Ravensburg in 1362-64, suggesting a particular enthusiasm for this mode of adornment and leniency in allowing for its extravagant development. ${ }^{30}$

While in the Weltchronik manuscripts examined here, Kruseler clearly herald the modes of the day, some images in the Munich codex use it to bind naughtiness of the present moment directly to idolatry of the biblical, mythological, or Roman past. In one illumination, the Midianite women, who were said to have seduced the Israelites by enticing them to idolatry and who were therefore slain, are shown wearing Kruseler as well as fur stoles (fol. 119r). More overtly, an image of the idolatry and unchastity of Israel includes women marked as venal by their dress (fol. 117v), and a scene of Paris embracing Venus has the couple standing before an idol in a shrine, and the goddess wears Kruseler along with pelts (fol. 155r) (plate 6).

Idolatry continues as a recurrent theme in the Regensburg and New York manuscripts, though in these codices the practices are less overtly tied to the contemporary moment. Idolatry comes to the fore, for instance, in the Regensburg work in a sequence of images on the practices of the ancient Romans (fols. 114v-115v; Jans der Enikel's Weltchronik 1l. 20273-20411). Each day of the week, one idol or another is venerated, so on Mondays, the text reports, an innocent child (ungemeilten kint, l. 20275) brought candles to a shining god of the moon, depicted as a monkeylike idol (fol. 114v), and on Wednesdays merchants showed particular veneration to Mercury, offering the ancient god luxury fabrics of the late medieval era - velvet, silk, and taffeta (samît, purpur und zendâl, l. 20321) (fol. 115r; plate 7). The Wednesday

6 Paris Embraces Venus, from a World Chronicle, BavariaAustria, c. 1370. Munich: Bayerische Staatsbibliothek (Cgm 5, fol. 155r). Photo: Bayerische Staatsbibliothek.

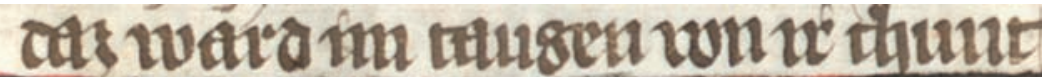

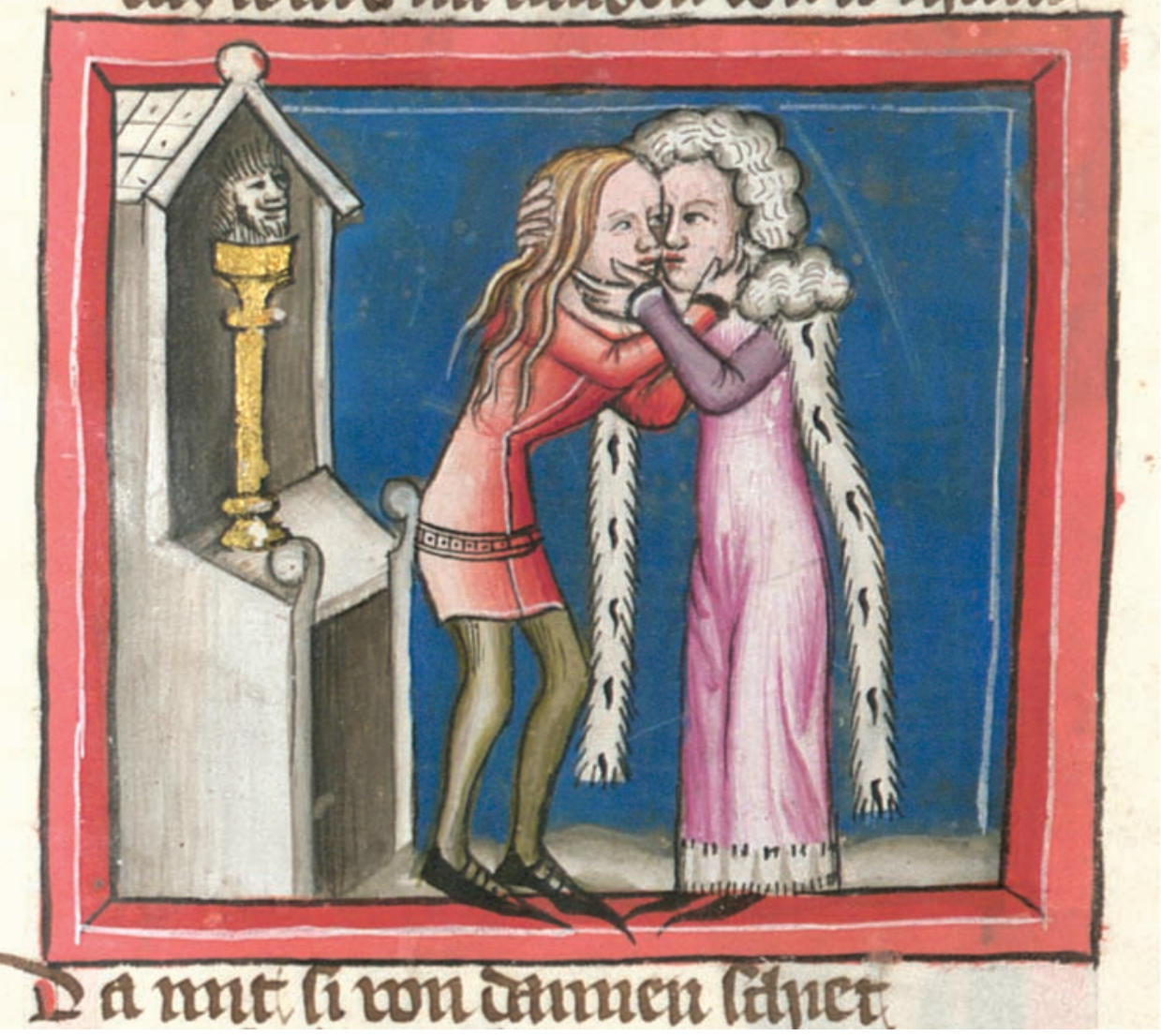


7 Practices of the Romans: Wednesday, Merchant Brings Cloth to an Idol of Mercury, from a World Chronicle,

Bavaria, c. 1360. Regensburg: Fürst Thurn und Taxis

Hofbibliothek (Ms. Perg. III, fol. II5r). Photo: Fürst Thurn und Taxis Hofbibliothek.

8 Ishmael with an Idol and Quarrel of Ishmael and Isaac, from a World Chronicle, Bavaria, 1402. New York: Spencer Collection, New York Public Library (Ms. 38, fol. 28v). Photo: Spencer

Collection, The New York Public Library, Astor, Lenox, and Tilden Foundations.
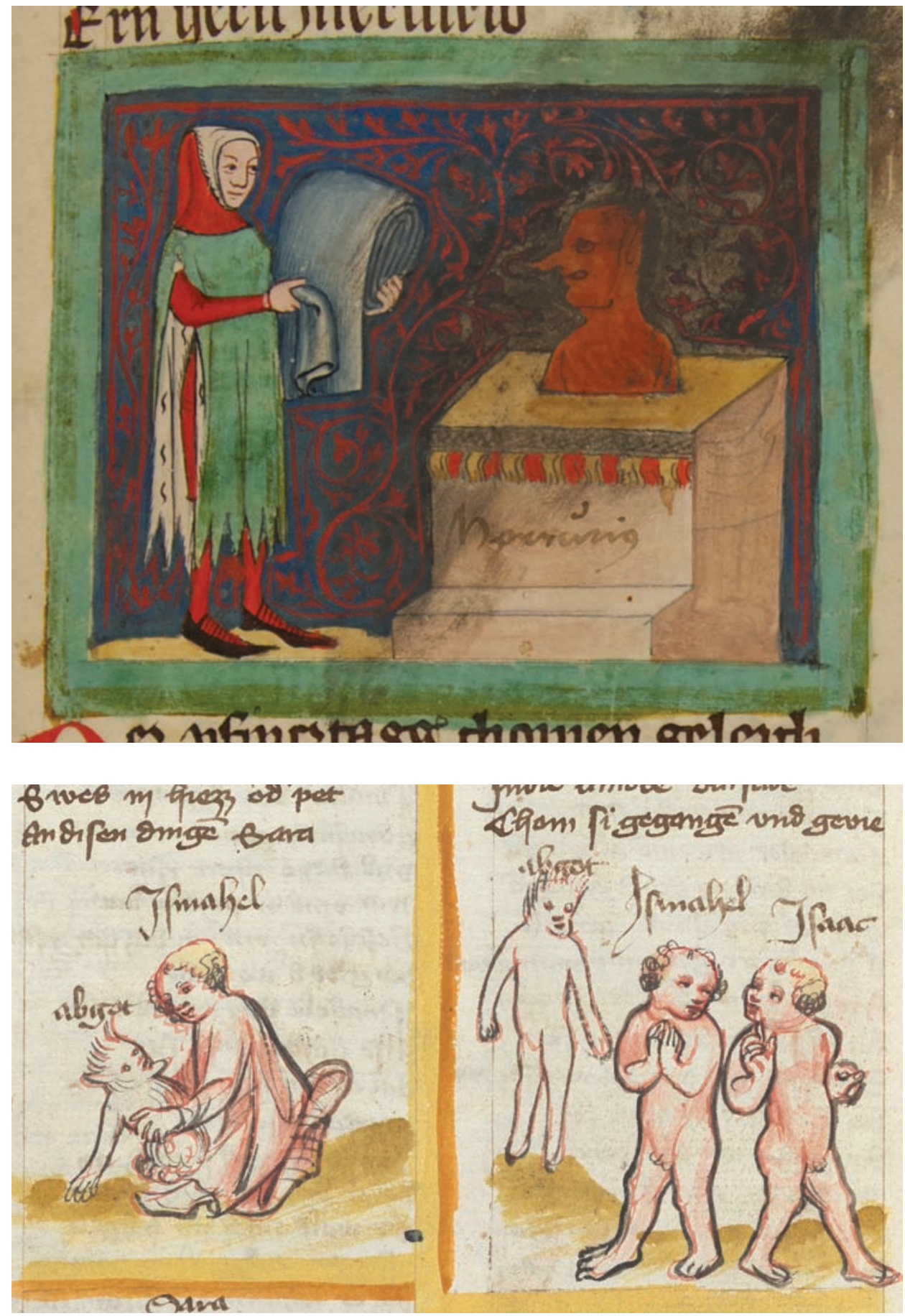

illumination invokes the tastes of the fourteenth-century urban realm, showing the merchant wearing the Gugel (pointed hood) and Husse (a mantel, open at the sides) that were popular with well-heeled urban men of the day. A similar sequence, it should be noted, appears in the Munich World Chronicle, fols. 184r-185r, culminating in an image of a man and woman sacrificing to Saturn, the woman wearing Kruseler (fol. 185r). The New York manuscript lacks a series on the practices of the ancient Romans. But images of idolatry surface throughout the work and captions take pains to identify the idols in the scenes, using the Middle High German term abgot as a label. In an image of the idolatry of the Greeks, for instance, the designation abgot hovers before a horned and tailed figure behind which is a looming devilish figure (fol. 12v). And in 


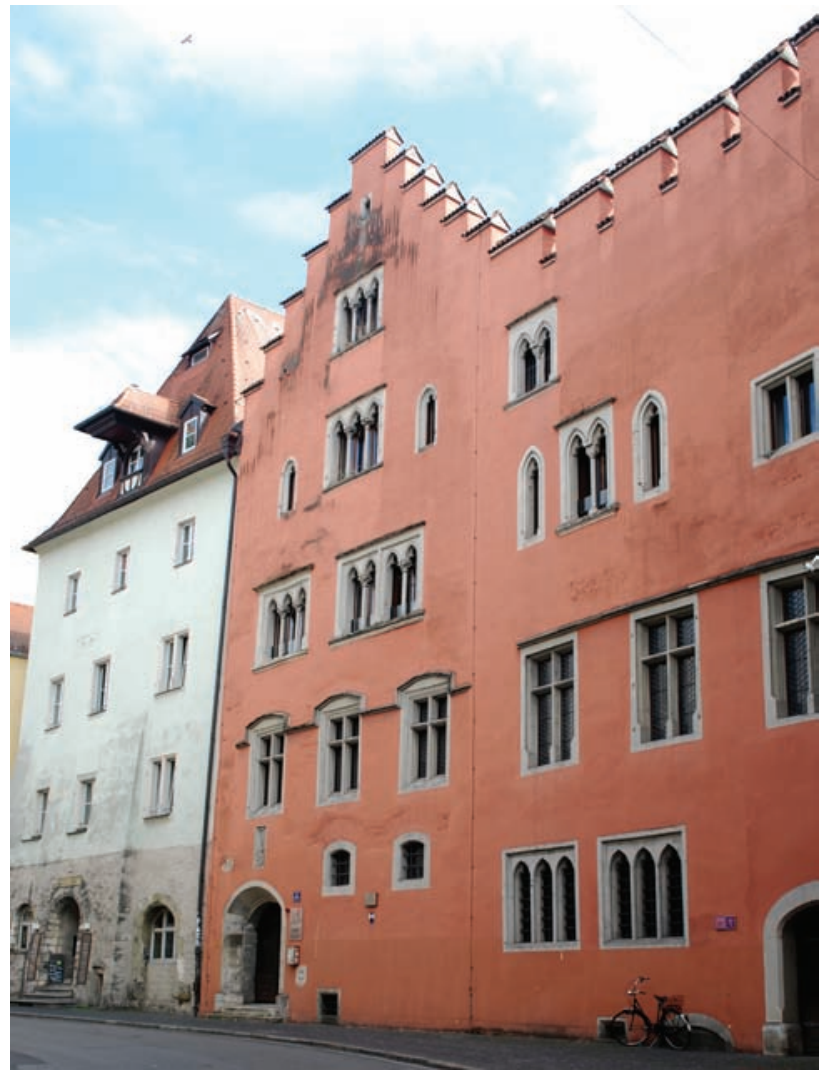

9 Runtingerhaus at Keplerstraße I, Regensburg, Germany, mid-fourteenth century. Photo: Author. scenes of the infant Ishmael and Isaac with idols, abgot figures similarly are labeled (fol. 28v; plate 8).

As mentioned already, it seems there were a range of urban centres for the production of illuminated Weltchroniken. The examples under consideration here have been localized to southern Bavaria, the Danube region, and Austria. One Bavarian city, laying along the Danube as it snakes into the Austrian realm, retains its late medieval profile to a remarkable degree and helps evoke the milieus in which the manuscripts under investigation were made and consumed. This site is Regensburg, a cathedral city and mercantile hub, still with a tangle of medieval streets at its centre, and wellpreserved examples of the kind of patrician houses inhabited by owners of illuminated Weltchroniken. ${ }^{31}$ One such urban palace is the Runtingerhaus at Keplerstraße 1 (now home to Regensburg's Amt für Archiv und Denkmalpflege) (plate 9). ${ }^{32}$ Wide and low, this rich city palace was constructed in the mid-fourteenth century, and is perhaps the best-preserved example of a façade marked with a stepped gable and crenellation. Remains of tiles and tracery reveal the structure's original rich ornament throughout, and there are particularly revealing remains in the building's great hall, a space for domestic entertainment, where chalk underdrawings affirm that originally the walls were adorned with images of weapons, animals, and grotesques. Similarly lavish and also laying at the heart of Regensburg was the Baumburger Turm at Watmarkt 4, extending up seven stories, each featuring pointed windows and bar tracery. ${ }^{33}$ Constructed in the third quarter of the thirteenth century at the earliest, traces of paint suggest how owners throughout the late Middle Ages sustained the vivid and luxurious appearance of this home. An original layer of orange-red paint was found throughout the building's interior. A second layer shows that the walls and ceiling vaults were painted a dark, almost violet red, while ribs and ornamental pillars were a strong golden yellow. Keystones, crafted in the form of leaves, in turn, were dark green, with red centres for those on the north side of the house and with yellow stars for those at the south. One can picture the Runtinger and Baumburger homes as settings where richly illuminated Weltchroniken were at the centre of evening entertainments. As a household member read the lively verse, those in attendance could see their own rich surroundings echoed in the multicoloured worlds painted in tempera and wash on the pages of the books.

At the centre of the network of streets that made up the urban terrain of Regensburg stood the city cathedral (plate 10). ${ }^{34}$ In 1273 construction of a new building was begun just to the west of the site of a previous Carolingian-Ottonian structure, and around a decade later an architect immersed in the modern style took on the project, plotting the cathedral following principles crystallized in France. It is an axial building, with nave and aisles articulated by piers formed from clustered colonnettes, extending into ribbed vaults. By the period around 1335-50, in the decades just before the creation of the Weltchroniken now in Regensburg and Munich, Regensburg Cathedral was far enough along that the three-storey elevation, with triforium and large clerestory windows, was complete in several bays extending west 
from the transept. Eventually overcoming a local faction resistant to demolishing a previous structure, by the opening years of the fifteenth century, when the New York Weltchronik was made, work on Regensburg Cathedral had progressed westward, all the way to the completion of the elaborate lower portion of the west façade

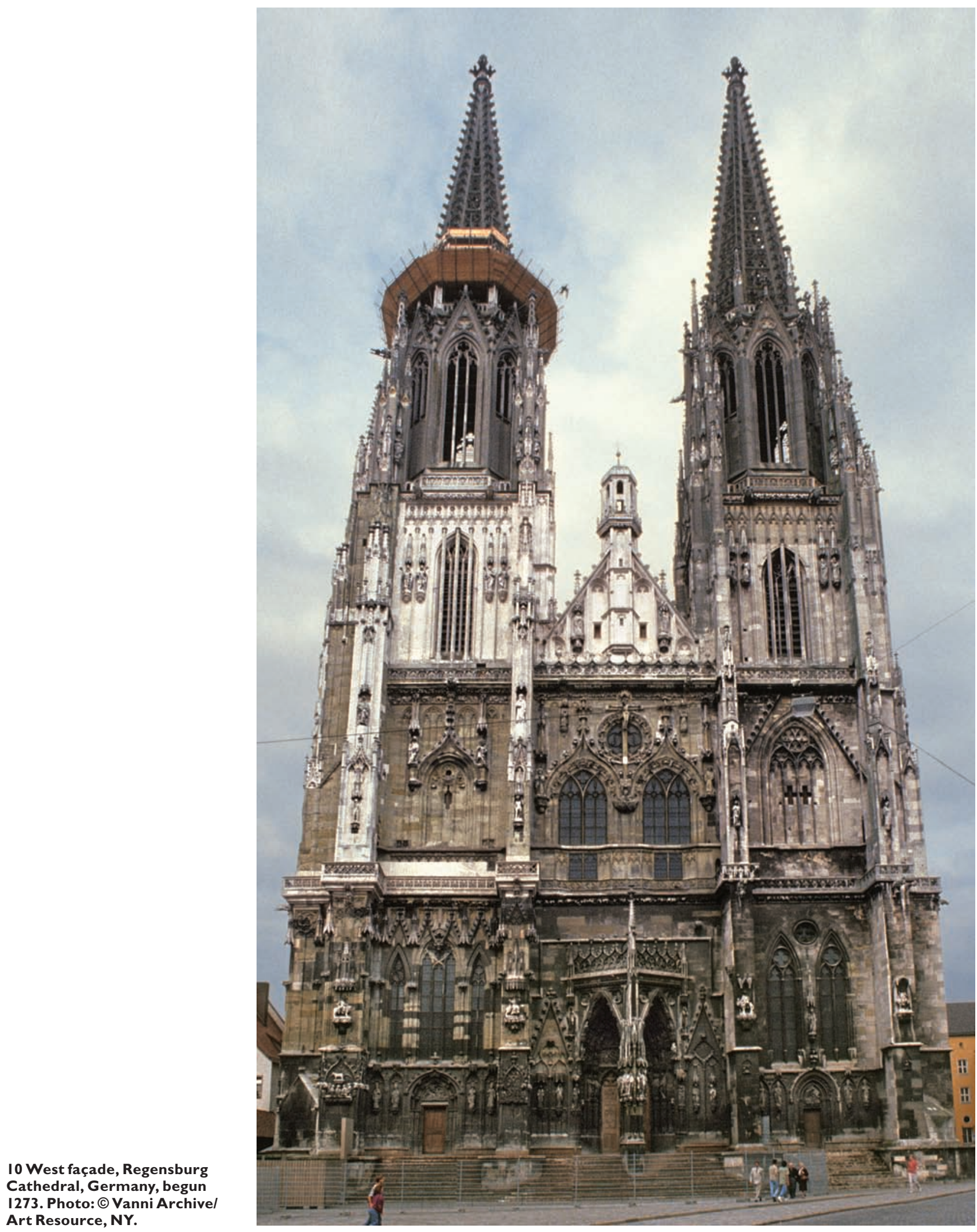




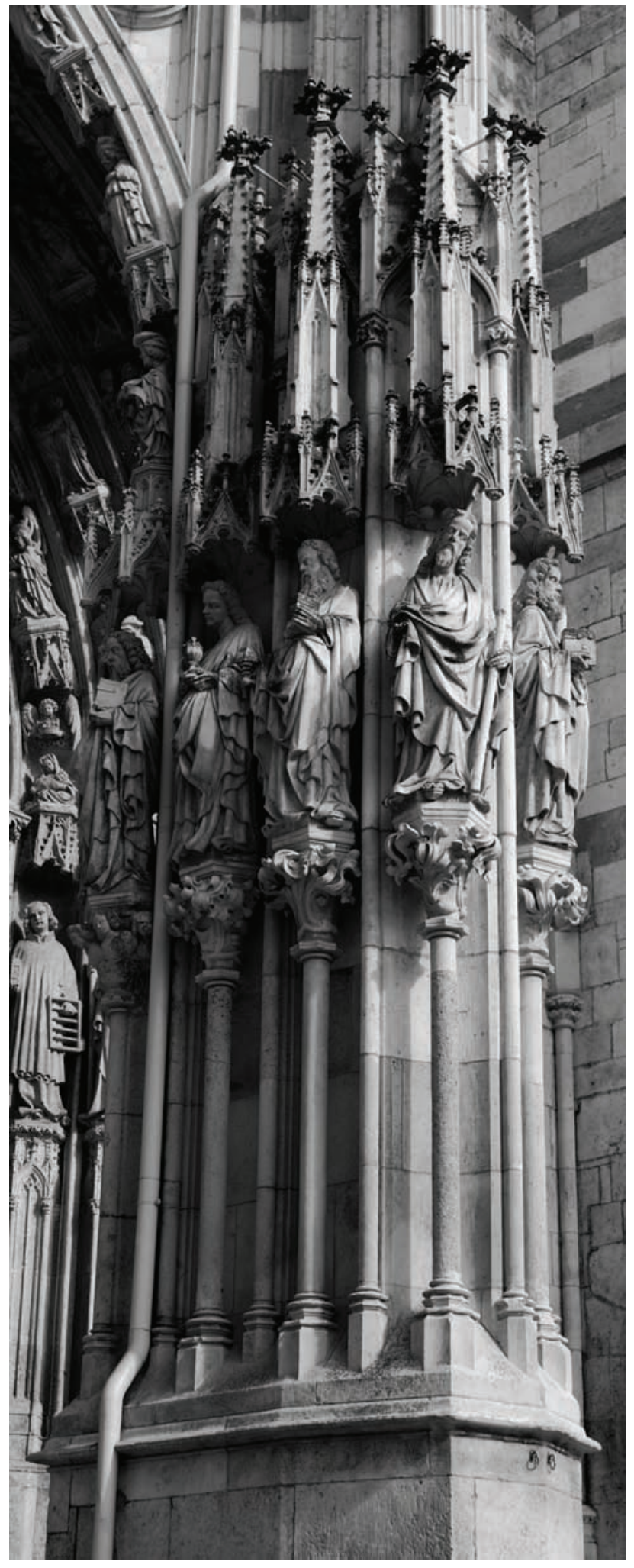

(though the upper storeys remained unfinished until c. 1495). While the soaring spires of the cathedral's western towers, with their rich crocketing and finials, today are a signature element of the Regensburg skyline, these structures were not built until the mid-nineteenth century. Nonetheless, the levels of the building that were complete in the years when illuminated Weltchroniken were in fashion had been fitted with crockets and finials much like that depicted in the Babylonian idolatry scene of the Munich World Chronicle. At the lavishly ornamented west façade with its triangular portal (c. 1385-1415) one finds multiple sculpted figures on addorsed colonnettes, beneath steeply gabled baldachins, capped with finials (plate 11). But also more modest portions of the building, like the western half of the southern flank, with bays marked by multiple pinnacles, attest to the floriated finial as a hallmark element of the modern building style of Regensburg Cathedral - as well as of so many other new churches in urban centres in the Bavarian and Austrian regions, including Sankt Lorenz in Nuremberg (begun c. 1250) and Vienna's Sankt Stephan Cathedral (mid-fourteenth century). The illumination that opened this discussion (see plate 1) uses the profile of the finial as well as modish dress to tie an act of idolatry at Nebuchadnezzar's ancient Babylonian court to the fourteenth-century present. This image and others like it seem to condemn the built environment of the late medieval Christian realm as one tainted with idolatry. In the streets of the cities where illuminated Weltchroniken were created and circulated, more vociferous dissidents voiced their antipathy in plainer terms.

\section{Dissent in the Streets}

Four decades ago, Horst Bredekamp published his provocative study of medieval iconoclasm, entreating art historians to consider the degree to which images were instruments of ecclesiastical power in the Middle Ages and to recognize that resistance to image-centred devotion could be understood as a radical act of rebellion. ${ }^{35}$ Bredekamp's trenchant analysis of the image culture in fourteenth-century imperial-ecclesiastical circles in Prague, and the Hussite hostility to it, is a landmark in the literature of art history and, along with his consideration of
I I Detail of triangular portal, Regensburg Cathedral, Germany, begun c. 1385. Photo: Author.
Late Antique and Byzantine iconoclastic movements, demonstrates the value of considering 'Art as a Medium of Social Conflict', in the words of his title. While texts connected to the Hussite thinkers examined by Bredekamp circulated in Europe, rendering consideration of their positions relevant beyond the bounds of Bohemia, more immediate evidence of anti-church sentiment in Bavaria and Austria appears 
in written works connected to the Waldensian populations of the region, directly in the territories where illuminated Weltchroniken were made and used. Texts penned by adversaries of those heretics speak to the contexts of production and reception for illuminated World Chronicles. And the extent of this movement and the positions advanced by its adherents help amplify otherwise muted voices of dissent that echoed through the streets in and around cathedral cities like Regensburg, c. 1360 to 1400.

The Waldensians were known in their day among themselves as 'the Poor of Lyons' (after the city of their founding) or the 'Poor of Christ', monikers that convey the fundamentally apostolic principles of the group, set in opposition to what they saw as the ostentation as well as sacramentalism at the heart of Christian practice. Key tenets of Waldensianism - the rejection of the doctrine of Purgatory, refusal to take oaths, insistence on the lay study of scripture - are well known and need not be reviewed here. ${ }^{36}$ What is critical for the present discussion is how widespread the movement apparently was across the Germanic region where illuminated Weltchroniken were in vogue and how steady was the Waldensian scorn for sacred images - dampnant et reprobant ymaginum veneraciones (they condemn and reject the veneration of images), in the words of a standard anti-Waldensian inquisitorial text. ${ }^{37}$

There is evidence of Waldensian communities across the Holy Roman Empire in the late thirteenth through fifteenth centuries. ${ }^{38}$ From about 1260 on, Waldensians are reported in lands stretching from the Rhineland, through southern Germany including Bavaria, east through Austria, Bohemia and Moravia, and north to the Baltic. In the regions of Bavaria and Austria in particular, in the zone around the Danube between Passau (a day's walk to Regensburg) and Vienna, the movement was particularly entrenched, being evident in over forty parishes. ${ }^{39}$ And across this terrain, Waldensians were found in all ranks of society, from farmers and village handworkers to the kinds of well-heeled urban tradespeople, patricians, and members of the lower nobility who would have owned or circulated through urban palaces like the Runtinger Haus or the Baumburger Turm in Regensburg. ${ }^{40}$

Waldensians were not left to pursue their beliefs unhindered. We know of their existence to begin with thanks to inquisitorial records and tracts condemning them. ${ }^{41}$ Among the most ardent opponents was the inquisitor Peter Zwicker, who, between 1391 and 1404, spearheaded a sweeping and systematic campaign aimed at converting Waldensians to orthodoxy over a swathe of the German-speaking realm from the Baltic to Austria. In his anti-heretical tract, Cum dormirent homines (1395), Zwicker celebrates his success at having already brought more than two thousand Waldensians to orthodoxy in Thuringia, the Mark Brandenburg, Bohemia, and Moravia, and he anticipates some one thousand further trials in and around Austria. ${ }^{42}$ Surviving manuscripts suggest a particular enthusiasm for Zwicker's text, and perhaps anxiety over expanding numbers of Waldensian heretics, in southern German and Austrian territories. ${ }^{43}$

In Regensburg in particular, there are reports that between 1380 and 1400 there were at least two persecutions of Waldensians and there is vivid evidence of the work of an inquisitor in the city, a certain Martin von Amberg, who may have been involved in one or both of those trials. A man and wife, Conrad and Elizabeth Huter of Regensburg, made confessions to this inquisitor in the 1380s and apparently renounced affiliation with the Waldensians, though it seems that various members of their family did not, and were burned at the stake. In 1393 Conrad Huter surfaced again, when he was sought out by a Waldensian visiting Regensburg, presumably hoping for hospitality based on the fact that Huter had sustained his Waldensian acquaintanceships, as attested by an alleged visit with members of the community in 1391 in Donauwörth (about $145 \mathrm{~km}$ upstream from Regensburg). ${ }^{44}$ 
Self-styled successes of Peter Zwicker, Martin von Amberg, and other inquisitors aside, the high tally of those brought before tribunals evinces the far-reaching appeal of Waldensian objections to the institutional church. One early fifteenth-century account reports of an apostate who scorns the clergy for venerating an idol (idolum) on Good Friday, stating that on this day, the priests and monks - the 'fornicators' play with puppets and idols (Hodie concubinos et cucullatos pupis et caudicibus lusuros esse).$^{45} \mathrm{In}$ light of this complaint it is hard not to think of late fourteenth-century Pietà groups with removable figures of Christ or crucifixion corpuses with movable arms, image types that became commonplace in the southern German and Austrian orbit in the late fourteenth century and after. ${ }^{46}$ Peter Zwicker entitles a chapter of his antiheretical tract De incredulitate imaginum (chapter 33), and in it he denounces those "who will not bend their knees before an image of a crucifix' (Non curuas genua ante imaginem crucifixi). ${ }^{47}$ Elsewhere he laments over those Waldensians who 'will not sing in church until their voices are hoarse' (Sed tu mute Waldensis haeretice ... nunquam cantas, nunquam ad raucedinem illi clamas). ${ }^{48}$

There were, however, those who would participate in Christian rituals simply in order not to arouse suspicion. For, beyond the many who were executed for holding firm to Waldensian beliefs, there were multitudes who were jailed for their faith, or made to participate in public penances, or to wear special garb marking them as former Waldensian converts to orthodoxy. Given these harsh punishments, there was good reason to take part in the devotional practices of the dominant culture, while knowing that one was not subordinate to them. Fourteenth-century trial records attest to Waldensians who would confess to Catholic priests, all-the-while convinced of the ineffectiveness of the acts, ${ }^{49}$ who would douse themselves with holy water, but deny its sacred efficacy, ${ }^{50}$ and who participated in church services, but would leave the building saying to themselves '[Here] what one sings is lies; what one says is lies; what one seeks is lies' (Es ist gelogen was man singet; es ist gelogen was man saget; es ist gelogen was man suechet). ${ }^{51}$ It is easy to imagine that Waldensians or their sympathizers equally acquiesced to the veneration of statues, an act they may have considered idolatrous, but which it was easier to fake one's way through than to disavow.

In the period that saw the production of the Weltchroniken at the heart of this study, the final decades of the fourteenth century and the beginning of the fifteenth, Waldensianism was pursued and punished more ardently and publicly than in any previous era. ${ }^{52}$ Among many such accounts, in 1403 the inquisitor Peter Zwicker condemned a Viennese burgher, one Andreas Hesel, to participate in public rituals of atonement and to carry a penitential cross for a year. ${ }^{53}$ And on 9 September 1411 one Johannes Grießer stood in the south choir of Vienna Cathedral before the mayor, city officials, clerics, and others, and was condemned to execution by fire for relapsing into Waldensian practices. ${ }^{54}$ Along with other insults against the church, Grießer is said to have deemed requiem Masses to be lies and openly likened the endowment of chapels to the founding of bordellos.

With challenges to church authority and devotional practice publicly expounded by Waldensians in city squares - and the attendant public exertion and performance of ecclesiastical power - it is hard to imagine that members of the urban elite who owned Weltchroniken would not in some degree be exposed to the positions of Waldensians and to Waldensian scorn for the institutional church and its artistic trappings. The illuminator who created the idolatry image in the Munich World Chronicle discussed here (see plate 1) may not have travelled in Waldensian circles himself, but he seems to have anticipated that his audience might recognize 
his winking reference to an affinity between the idolatrous practices of the ancient Babylonian court and contemporary ecclesiastical structures, a linkage cemented through the figure of the elevated finial. If this scene of idolatry at Nebuchadnezzar's court overtly alludes to late medieval devotional practices, the sequences of vignettes illustrating the Daniel story in the Regensburg, Munich, and New York manuscripts probe further the distinction between licit and illicit signs, and gesture toward the social realm of the late medieval city. Images that dramatize the story of Nebuchadnezzar's dream and idol in terms that referred to the current age invited reader-viewers to question the religious imagery and adornment of the urban sphere as well as the commands of ecclesiastical leaders to bow down in pious deference.

\section{A Divine Dispatch}

In illuminated Weltchronik manuscripts, the motif of Nebuchadnezzar's dream typically opens the Daniel sequence, presaging overarching themes in the subsequent narrative concerning the nature and meaning of signs. In the Regensburg, Munich, and New York manuscripts, illuminators picked up on references in Jans der Enikel's text to the hallowed status of the dream as a message sent by God and it appears that they sought to convey this sacrality by rendering the dream figure as ethereal. That is, in contrast to other illuminated Weltchroniken, where images stress the corporeality and sometimes idol-like quality of the night-time vision of Nebuchadnezzar, ${ }^{55}$ in the works considered here, elements of draftsmanship and materials underscore the intangible nature of the dream figure. In conveying the figure's impalpability, I suggest, the illuminators set the dream-man as an example of the kind of divinely sanctioned image that is the very opposite of the satanic idol introduced later in the tale.

Jans der Enikel sets the terms, stressing the dream figure's ephemerality and divine quality. Despite a long pictorial tradition of showing Nebuchadnezzar's dream as a sculpture that actually materializes in the king's chamber, Jans's text suggests the dream's numinous nature as it 'came to his [Nebuchadnezzar's] heart' (ein troum im in sîn herz lief 1. 16956). Jans's account alters only slightly the biblical description of the dream figure as composed of four elements - the head is of shining gold, the chest and arms are of silver, the region from waist to knee is bronze, and from the knee down, the sculpture is iron. Only the proverbial 'feet of clay', mentioned in the Bible, are left out (Dan. 2:33). What is noteworthy is the word that Jans uses to describe the dream. He refers to this image repeatedly as ein bild (ll. $16957,16958,16960,17116$, and 17175), a term that, in German texts of the period c. 1200-1450, could indicate a painted or a sculpted representation but also an idea or an example. ${ }^{56}$ Later, after Nebuchadnezzar awakes, seeks an interpretation of the dream from his wise men, and kills those sages because of their inability to offer an explanation, the king turns to Daniel for his analysis. Because by this point the king has forgotten what his fleeting night-time vision looked like, Daniel seeks divine aid, and in return, 'the Lord made for him [Daniel] the image' (got im daz bild machte, l. 17116). 
The illuminator of the Regensburg manuscript used setting and materials to underscore the extraordinary nature of the image encountered by Nebuchadnezzar. The dream scene in this manuscript is set outdoors, with the king's bed lying on a grassy ground plane and beside a richly rendered tree (plate 12). The juxtaposition of rustic setting and the fully outfitted bed cast the whole encounter as patently apparitional. The crown on the king's head facilitates identification, but his eyes are shut and his shoulder is bare, suggesting he has happily prepared himself for rest and has fully drifted off. Into Nebuchadnezzar's reveries steps a shimmering man with arms raised as he approaches the bed. It appears that the illuminator first covered the dream figure with a red bole and then applied silver leaf. Though the silver now has partly oxidized, the resplendent nature of the form is still evident, even in reproduction. First-hand inspection reveals no contour lines on the figure itself, though it is possible these have flaked off over the years. What is clear is that, in contrast to other illuminated Weltchroniken in which the various materials from which the dream-man was fabricated - gold, silver, bronze, iron - are rendered through different paint colours or through juxtaposition of gold and silver leaf, the illuminator of the Regensburg manuscript found it sufficient to depict the dream bild simply as a glittering vision sent from on high, one that spurs the king to shake from fear (sîn lîp vor forhten krachet, l. 16974).

In the Munich manuscript, the mystical nature of the encounter is manifest through the otherworldliness of the dream form, juxtaposed to the concrete quality of the royal bed (plate 13). Here the setting has moved from the outdoors apparently to an internal chamber, suggested by the simple ground plane. Nebuchadnezzar lies in bed, bare shouldered and crowned, with eyes shut, as in the previous manuscript. But in this illumination, the artist has taken pains to convey the plasticity of the king's body, wrapped in a weighty red blanket that bunches, ripples, and droops toward the ground. Wooden posts anchor the bed to the floor and a perky pillow boosts the head and torso of the monarch. Entering the space of this sturdy sleeping king is the sparkling and sylphic dream form. With feet breaking the illumination's

13 Nebuchadnezzar's Dream, from a World Chronicle, Bavaria-Austria, c. 1370. Munich: Bayerische

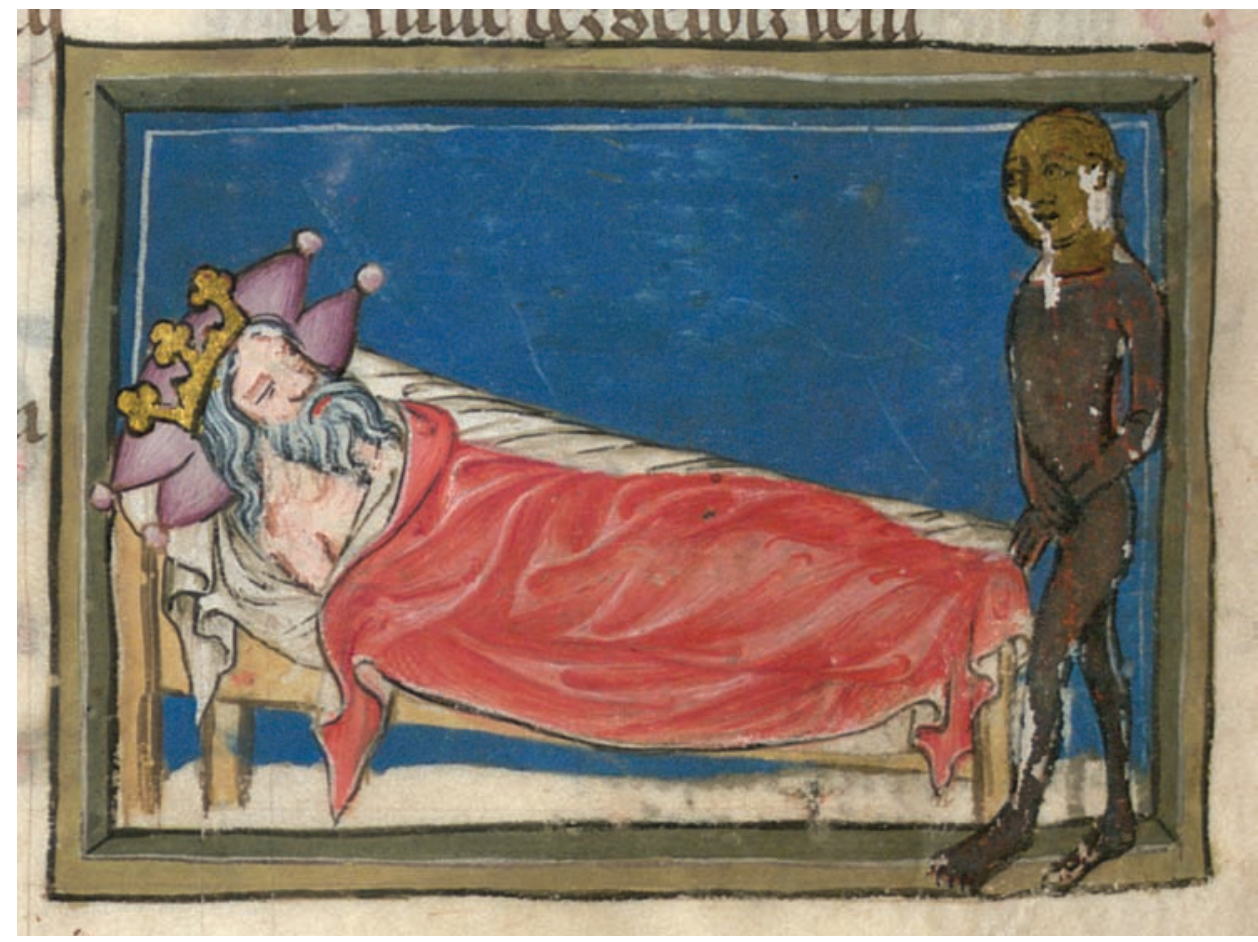




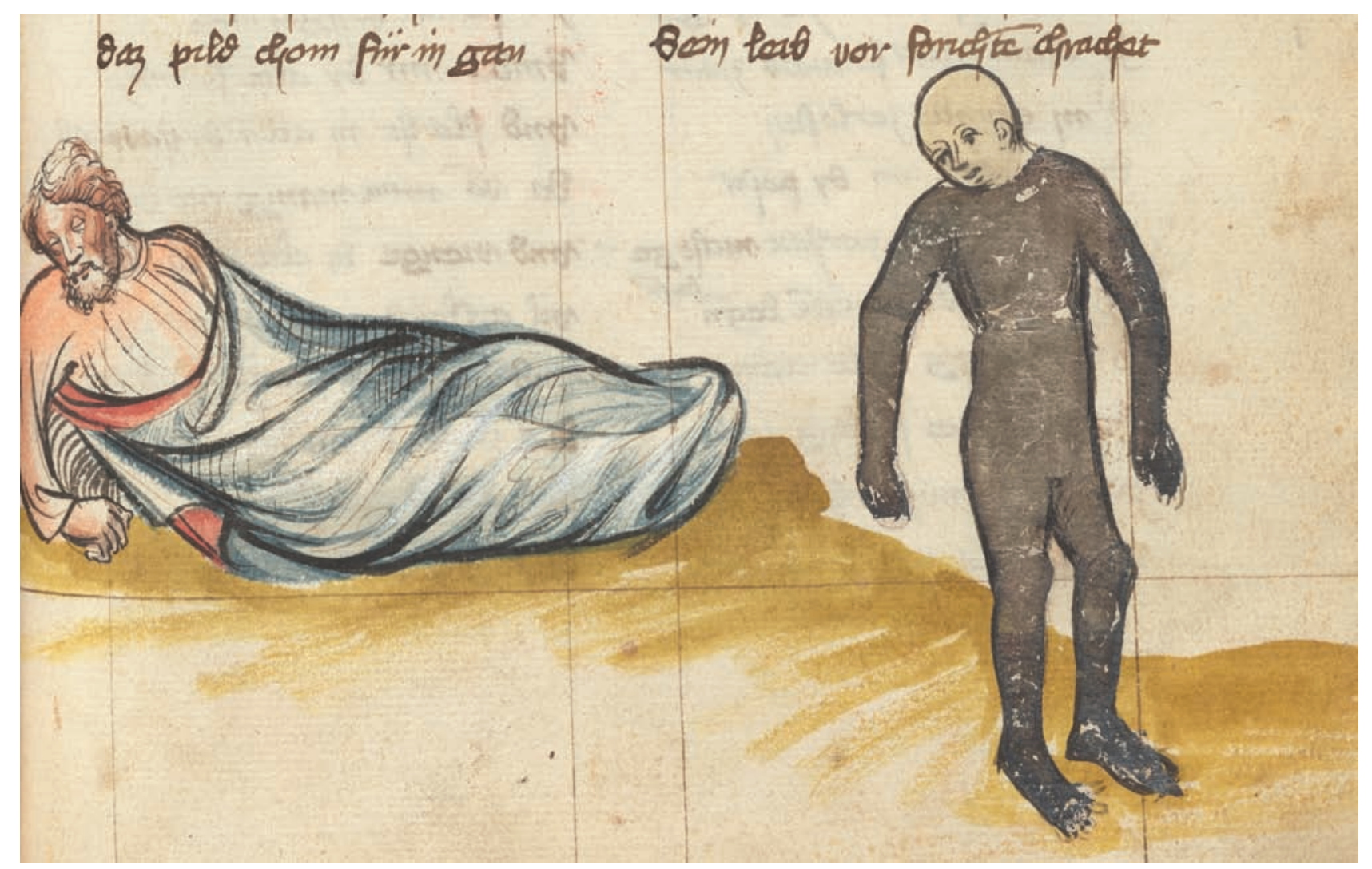

14 Nebuchadnezzar's Dream, from a World Chronicle, Bavaria, 1402. New York: Spencer Collection, New York Public Library (Ms. 38, fol. 312r). Photo: Spencer Collection, The New York Public Library, Astor, Lenox, and Tilden Foundations. frame, the figure seems to have just strutted into Nebuchadnezzar's mental terrain. The red colour now visible on the dream-man's body is a ground layer, over which the illuminator placed gold leaf at the head and silver leaf on the rest of the form. Viewing the illumination from an oblique angle, the golden head shines and the rest of the body, covered in a now-oxidized silver, similarly radiates. Aspects of the dream-man's form are echoed in other creatures depicted throughout the manuscript. But the lack of clothes on the dream vision underscores the figure's sloping shoulder, narrow waist, and slender thighs, tapering toward whispy calves and oversized feet, elements that contribute to the dream-man's sprite-like quality. Contour lines on the dream-figure's face mark him as humanoid, lending the form a familiarity that renders the dream-man's alien bodily characteristics all the more uncanny, and justifying the king's exclamation: 'Lord, what is this thing?' (herr, waz ist ditz dinc?, l. 16977).

The dream figure's curious character comes to the fore in the New York manuscript, where the illuminator sets the being apart from the sleeping king and emphasizes its alterity (plate 14). The paper medium of the New York codex allowed the illuminator to pursue a distinctive aesthetic, where images are rendered as if they exist directly on the page's surface, without restricting frames. Lacking a bed, un-crowned, and wearing a nightshirt, the king here does not follow iconographic conventions established in the previous two illuminations discussed, but the illuminator nonetheless emphasizes Nebuchadnezzar's corporeality in a manner that parallels the other examples. Delicately rendered hairpin loops delineate the folds of the king's blanket, and soft shadows convey the mass of his body. While the monarch's drooping head and closed eyes suggest a peaceful slumber, his right fist grips the bedclothes, an expression of interior agitation brought on by the dream. The fitful king, however, recedes to the background as the dream commands 


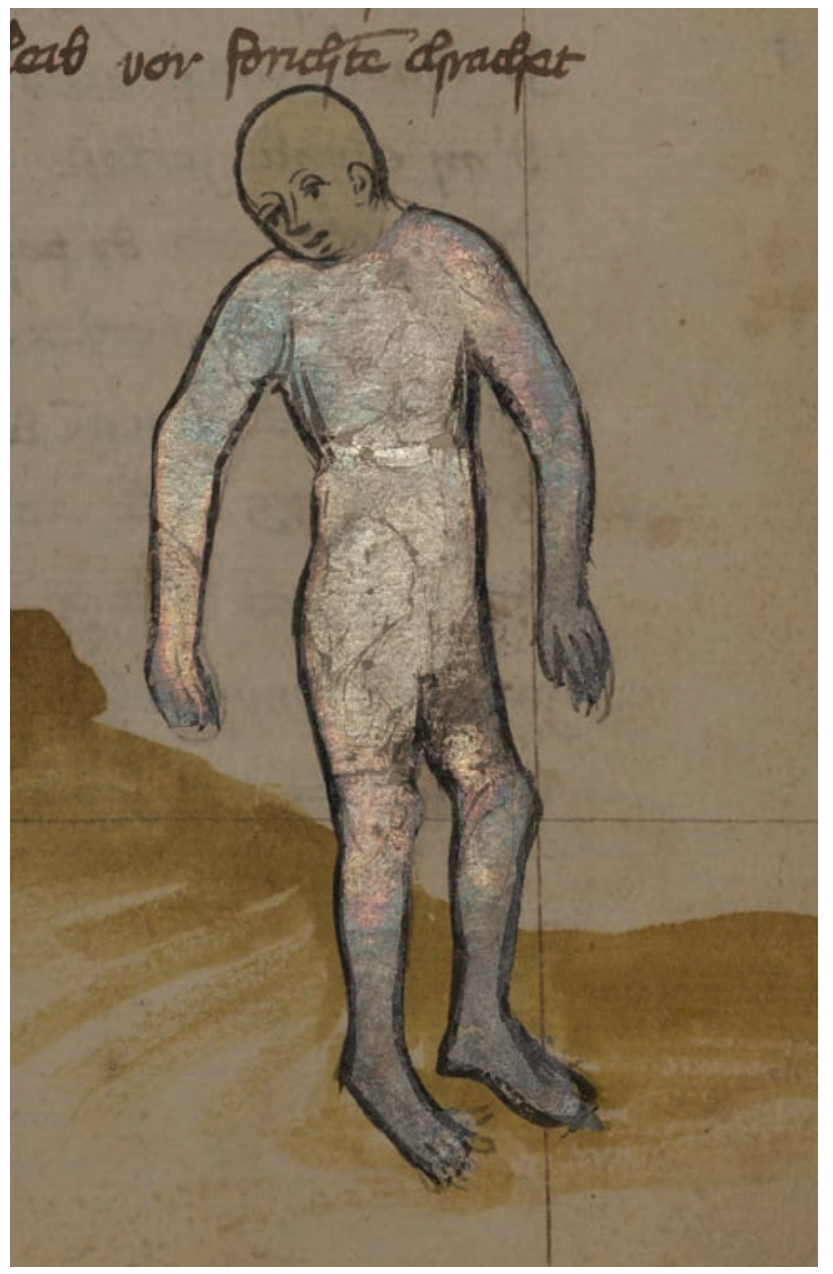

attention to his wondrous form. Rendered with a simple black contour line, the dream-man stands in contrapposto, with weight rested on the right leg, and the torsion of the body directed back toward Nebuchadnezzar. A photograph shot from an angle in raking light shows the iridescent quality of the silver here, granting the dream figure an unearthly glow (plate 15)..$^{57}$

Created across a span of roughly four decades, the illuminations in the Regensburg, Munich, and New York manuscripts display a shared drive to depict Nebuchadnezzar's dream figure as an intangible and bizarre form. Using draftsmanly devices and shimmering materials the illuminators of these images found varying pictorial means to bind the king to the terrestrial realm and the dream-man to the world of the spectral. In so doing, they announce the extraordinary nature of Nebuchadnezzar's dream as a bulletin sent by the Lord. This is a dispatch that was indecipherable to the ranks of the king's wise men, but, with divine assistance, was legible to Daniel. This vision that was created and licensed by God is the very opposite of the kinds of the material signs allegedly channelling divine glory set up at city centres across southern Germany and Austria - Schöne Madonna figures, crucifixions with moveable parts, and ecclesiastical buildings peppered with colonnettes, gables, crockets, and finials. It is those public signs

15 Detail of Nebuchadnezzar's Dream, from a World Chronicle, Bavaria, 1402, showing dream-man in raking light. New York: Spencer Collection, New York Public Library (Ms. 38, fol. 312r). Photo: Spencer Collection, The New York Public Library, Astor, Lenox, and Tilden Foundations. boasting of Christian triumph that inspired the ire of Waldensians, and apparently the derision of at least one illuminator (see plate 1).

\section{Satanic Spectacle}

If the night-time message sent to Nebuchadnezzar comes off as patently ethereal and celestial, the illuminators of the Regensburg, Munich, and New York manuscripts underscore the materially tangible and satanic nature of the idol that the king sets up once he awakens. In these manuscripts, over the course of a sequence of scenes presenting the veneration and destruction of the king's idol, word and picture suggest an equivalency between the idol of ancient Babylon and the pious acts performed within the ornamented ecclesiastical arena of the late Middle Ages. The illuminators of these images seem to delight in revealing the demonic nature of the idol and their images invite reflection on the base nature of the material realm in general and of decked out and festive devotional spaces in particular.

Jans der Enikel's text establishes a correlation between Babylonian idolatry and the elements of architectural structure and ornament by stressing that the idol set up by Nebuchadnezzar is a column. In the text, the Lord reveals to Daniel the meaning of the dream - that King Nebuchadnezzar's regime will be replaced by others, eventually that of Alexander the Great. Once Daniel informs the king of this, Nebuchadnezzar concocts a scheme to display his own authority, ordering the erection of an idol. The Vulgate account of this episode specifies that Nebuchadnezzar set up a golden sculpture (statuam auream, Dan. 3:1). In Jans's text there are multiple 
16 Veneration of

Nebuchadnezzar's Idol with

Strafe des Prellens, from a

World Chronicle, Bavaria,

c. 1360. Regensburg:

Fürst Thurn und Taxis

Hofbibliothek (Ms. Perg. III, fol. 97v). Photo: Fürst Thurn und Taxis Hofbibliothek. references to idolatry, using the Middle High German term abgot 111 times, by my count, throughout, sixteen of these in the Daniel and Nebuchadnezzar story (ll. 16933-18164, that is). The author, however, makes plain that Nebuchadnezzar's idol was not a generic abgot in the form of a golden statue, but rather was a column - a siul ${ }^{58}$ - as in this account of Nebuchadnezzar's thoughts when he first orders the structure:

I must so honour an idol / With goods, with people / That it may totally reverse / The power of this king [Alexander] / ...

ich muoz ein abgot alsô guot / mit guot, mit liuten êren / daz ez müg gar verkêren / des selben küniges gewalt / ... (ll. 17212-17215)

At once the king gave an order / To designate a place for the column

Zehant hiez der künic gâhen, / die stat der siulen vâhen (ll. 17227-17228)

The illuminators of the Regensburg, Munich, and New York manuscripts departed from their own conventions when they sought the means to depict Nebuchadnezzar's idol, focusing on its columnar nature. For throughout these manuscripts, idols in general appear variously as red steers, monstrous beasts shown bust-length, or homunculus forms, sometimes on a slender column, sometimes in a shrine, sometimes on an altar (see plate 6, plate 7 and plate 8), mostly conforming to trends throughout late medieval manuscripts. ${ }^{59}$ But in the Nebuchadnezzar sequences of the Regensburg, Munich, and New York manuscripts, the Babylonian idol is shown as a column or colonnette, fabricated from the materials of the contemporary built environment, and housing a satanic energy. The manner in which the idol is venerated in the three manuscripts, moreover, further tethers the images of biblical religious transgression to the current moment.

In the Regensburg manuscript, Nebuchadnezzar's idol references ecclesiastical structures of the fourteenth century, while people encouraging and resisting its veneration likewise appear in a contemporary idiom (plate 16). The illumination

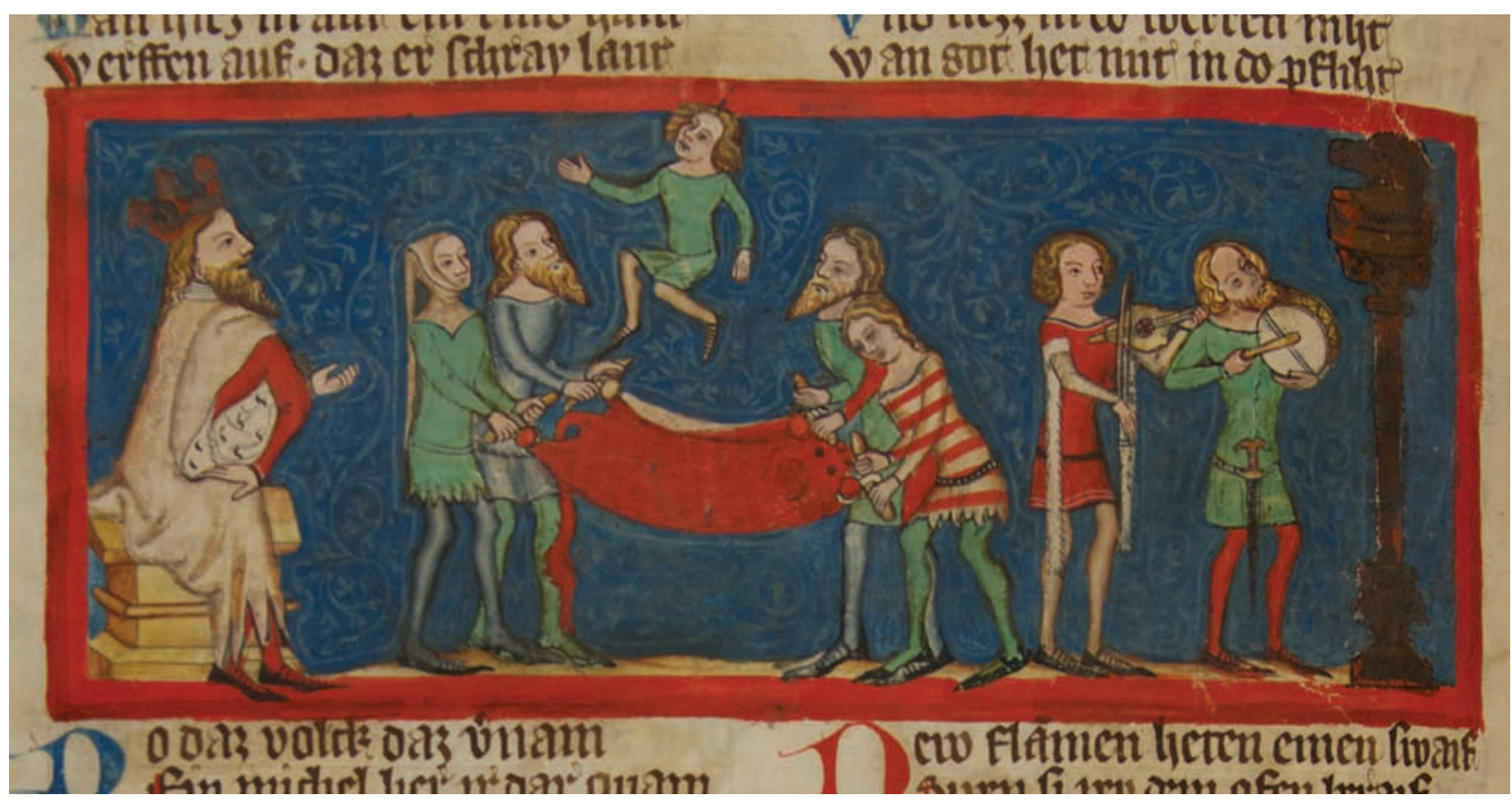


17 Nebuchadnezzar's Idol, from a World Chronicle, Bavaria, 1402. New York: Spencer Collection, New York Public Library (Ms. 38, fol. 3I5v). Photo: Spencer Collection, The New York Public Library, Astor, Lenox, and Tilden Foundations. shows the idol at the extreme right. Its slender columnar structure and gilding correspond to the golden siul described in Jans der Enikel's text. The capital and base of this column have leafy forms like the one in the Munich manuscript, discussed at the opening of this argument (see plate 1), and these echo the forms of crockets and finials commonplace in ecclesiastical buildings of the fourteenth century (see plate 10 and plate 11). Atop Nebuchadnezzar's siul is a sculpted head of a doglike creature, suggesting the beastliness housed within.

In Jans's account and in the Bible (Jans der Enikel, 1l. 17257-17268; Dan. 3:5, 7, 10, 15), Nebuchadnezzar has musicians brought in to play before his idol and ordains that, at the sound of their playing, people are to fall down in worship, or be killed. The text of the Vulgate specifies that Nebuchadnezzar calls in players of trumpets (tubae), flutes (fistulae), harps (citharae, sambucae and psalterii), and bagpipes or drums (symphoniae). In the Bible, the foreign names of these instruments mark their exotic nature, distinguishing them from standard instruments of the Israelites. Jans der Enikel, however, uses terms that would be familiar to his audiences - orgel (straight trumpet or pipes), rotte (harp), gîge, herpfe and vetach (harp or stringed instruments, some played with a bow), and sumber (drums) (1l. 17258-17261)..$^{60}$ These were the instruments of secular pageantry, instruments that would be played at court and in city streets on festival days. In the Regensburg illumination, the king appears at the left extreme, ordering the celebration of his siul, and obedient musicians, wearing the fashions of the fourteenth century, comply. A youth, dressed in a short red tunic, enhanced by fur trim that hangs from the sleeves, draws a bow over his instrument, while his older bearded companion has on a fitted green tunic and red leggings and bangs on a drum. But at the centre of the






\section{Destruction of \\ Nebuchadnezzar's Idol, \\ from a World Chronicle, \\ Bavaria, c. 1360. Regensburg: \\ Fürst Thurn und Taxis \\ Hofbibliothek (Ms. Perg. III, \\ fol. 99r). Photo: Fürst Thurn \\ und Taxis Hofbibliothek.}

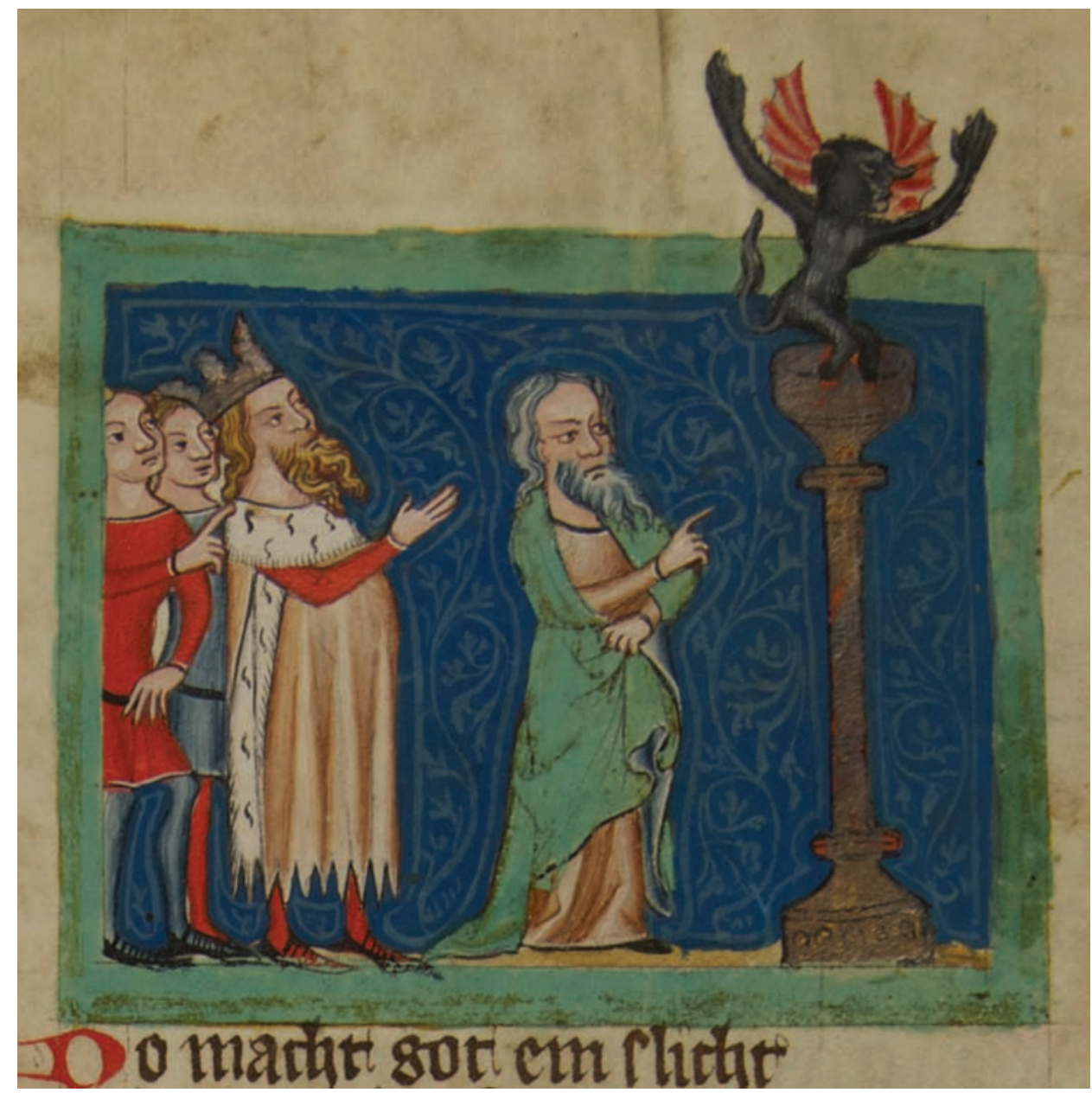

scene is a youth who did not fall to his knees before the idol when commanded to by the king or when egged on by the musicians. This unfortunate young man is being bounced aloft on a cow skin, held at the corners by servants. Catalogues of illuminated Weltchroniken identify this motif as the Strafe des Prellens, or bouncing punishment, and Jans der Enikel's text explains that those who approached Nebuchadnezzar's idol wearing improper garb were thrown in the air on a hide, so that they would call out loudly (man hiez in ûf einer rinderhût/ werfen ûf, daz er schrê lût, ll. 17273-17274) ${ }^{61}$ This motif seems to reference contemporary custom, a form of discipline, apparently typical in circles of students, guilds, and militias. For those familiar with heretical commitments, however, it would be hard to avoid reflection on Waldensian resistance to imagecentred devotion when viewing such an overt depiction of punishment for refusal to genuflect before a sculpture on a golden colonnette.

The idol scene in the New York manuscript similarly includes prompts to meditation on late medieval pious practices - and objections to them (plate 17). Here the siul dominating the centre of the image is rendered in pink and heightened with loose white and red brush strokes, suggesting it is fabricated from veined marble in the manner of an ancient column. But the musicians at the left, as in the Regensburg illumination, register the practices of the contemporary moment. For it appears that Nebuchadnezzar, depicted at the right, consulting with courtiers, has just commanded the players to sound their instruments, an encouragement for those who, from among the great crowd, did not want to praise the pillar with song (von grôzem gedrange/ swer dô niht mit gesange/ die siul wolt êren, ll. 17251-17253). The 
19 Destruction of

Nebuchadnezzar's Idol, from a World Chronicle, Bavaria-

Austria, c. 1370. Munich:

Bayerische Staatsbibliothek (Cgm 5, fol. 17lv). Photo:

Bayerische Staatsbibliothek.

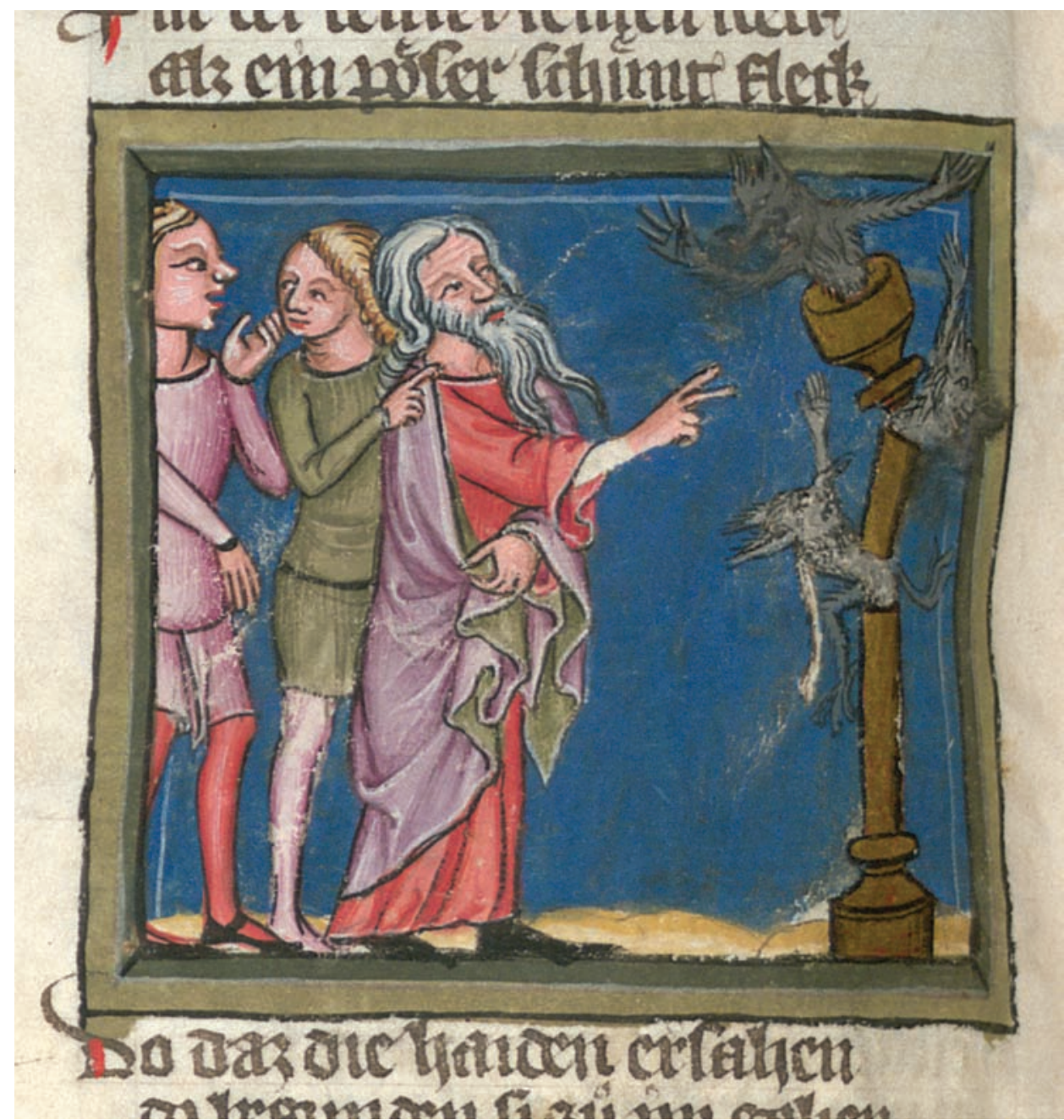

music makers depicted in the New York manuscript seem to play with gusto and are dressed to entertain, twirling around in the tight hose and short fitted tunics. Seeing this pictorial evocation of the boisterous musical veneration of the idol ordained by Nebuchadnezzar, reader-viewers might recall Waldensian resistance to Christian celebration in song - the so-called heretics who denounced the church for compelling devotees to 'sing lies', or the inquisitor who bemoans those who refuse to sing in church 'until their voices are hoarse'. ${ }^{62}$ In the understanding of those sympathetic with Waldensian plaints, Nebuchadnezzar's idolatrous musical celebration could find reverberations in the polyphonic chant wafting through the churches of the present day.

But in the plainest terms, it is the devil, as depicted in the Weltchroniken, which overtly manifests the unholy nature of the fabricated foci for devotion. Jans der Enikel's text repeatedly refers to the devil residing within Nebuchadnezzar's siul (ll. 17288, 17400, 17417, 17571) and Satan even is said to emerge in order to read to the people, as if from a sermon, 'what was pure heresy' (dâ der tiufel inne was/ und den liuten ûz der siul las/ mit sînem mund vil frî/ die lûter ketzerî, ll. 17417-17420). The New York illumination of the idol presents an anthropomorphized devil, whose head pops out from the column and seems to strain to capture the attention of Nebuchadnezzar and his courtiers (see plate 17). The Regensburg and Munich illuminations lavish more attention on the drama of the column's destruction, something that happens after 
20 Michael Ostendorfer, The Pilgrimage of the 'Fair Virgin' in Regensburg, woodcut, Germany, c. 1520. Hamburg: Hamburger Kunsthalle (Inv. 32780). Photo: Christoph Irrgang/Art Resource, NY.
Daniel engages in a long debate and the king challenges the Lord to show his power by destroying the idol. As the text describes it, God made a crack in the column, out of which the devil, in the form of a disgusting, stinking, hairy mess, emerged (fuor der tiufel sinen wec/ als ein ungenaemer, stinkender flec, ll. 17571-17572). ${ }^{63}$ In the Regensburg manuscript, the illumination of this scene shows Daniel commanding the action at the centre of the image, while Nebuchadnezzar and his courtiers cluster behind (plate 18). At the right is the siul, shown as an ornamented gold colonnette, though without the doglike head at the top as in the previous illumination (see plate 16). Instead, emerging from the column's capital is a devil, exquisitely modelled in black, grey, and white and with red, batlike wings. This scowling creature raises his arms as he seems ready to take flight, banished from the colonnette he called home. In the Munich illumination of this episode, the column that previously had been shown

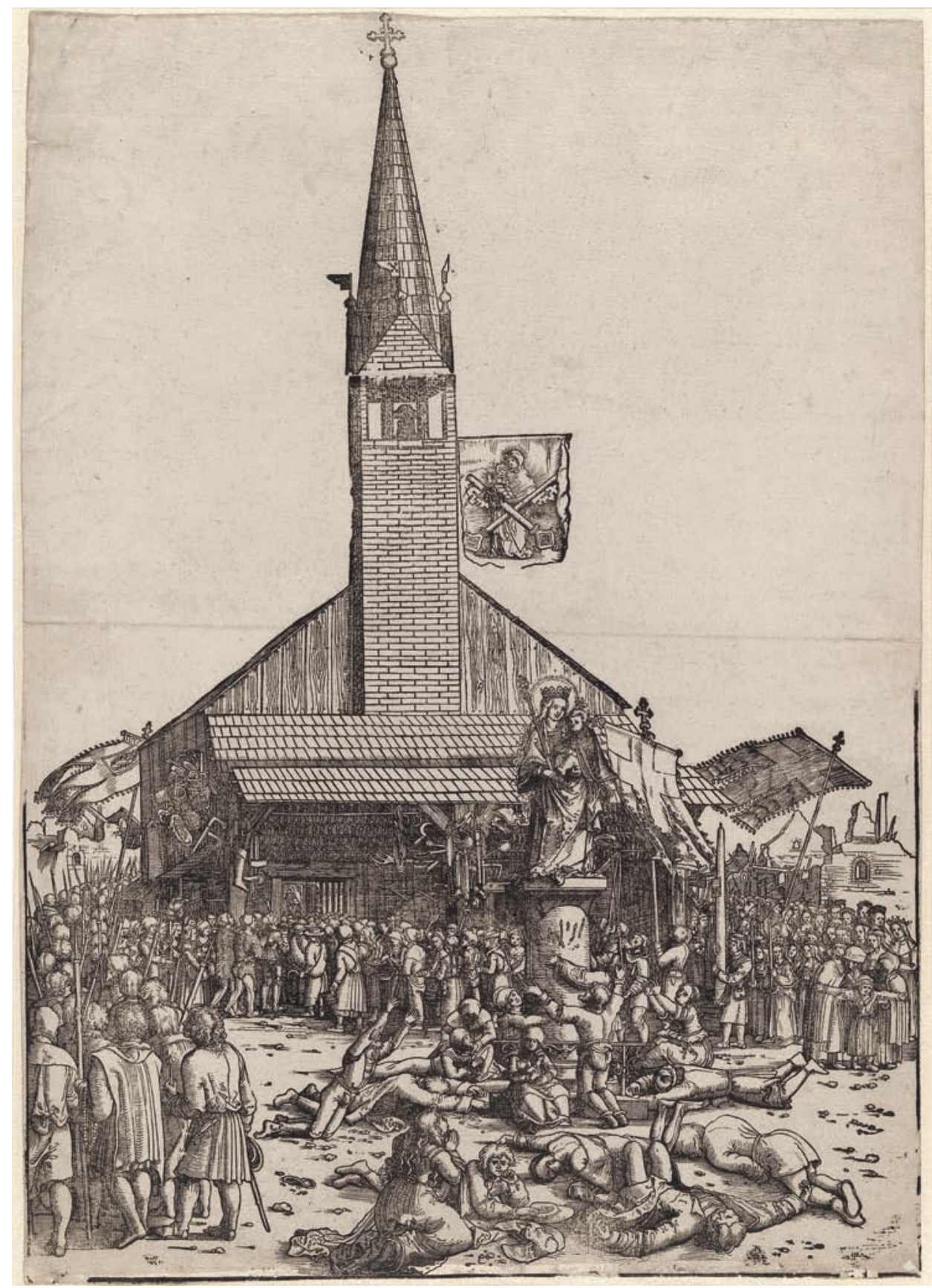


heavily ornamented with finial and floriated base (see plate 1) is rendered as a stripped down simple golden colonnette, out of which emerge three beastly devils (plate 19). As this structure cracks and shatters under the eye of Daniel and two courtiers, two fuzzy beasts burst out, while at the top, a menacing wolf-like creature seems to roar, ready to lunge forward with outstretched arms. In these culminating scenes of the dream-and-idol sequence, Nebuchadnezzar's siul is shown to be a Satanic structure, worthy of being smashed.

While in the years around 1420, Hussites in the Bohemian realm would famously destroy sculptures and paintings they deemed to be idolatrous, often declaring that such images had the devil within them, the Waldensians and other doubters about the propriety of image-centred devotion in the Holy Roman Empire took no such radical or coordinated action. ${ }^{64}$ The monumental and richly ornamented structures of the church would endure, built ever higher. Inside and in front of these buildings, image-centred devotion would thrive, sometimes amplified to the point that it grew embarrassing for church authorities or the more sceptically minded, as documented in Michael Ostendorfer's woodcut of c. 1520, condemning veneration of the sculpture of a Virgin raised up on a column at Regensburg (plate 20). ${ }^{65}$ The text of Jans der Enikel's Weltchronik mocked devotees captivated by Nebuchadnezzar's ancient idol, saying the devil who resided within it preached to them 'pure heresy'. Meanwhile, Waldensians who resisted veneration of the images they considered to be idols were flogged, branded, and burned as heretics themselves. These dissenters did not organize campaigns of image destruction, but they or those who sympathized with them could find hope in the images of the destruction of Nebuchadenzzar's idol in illuminated Weltchroniken. Set in opposition to the spectral figures of Nebuchadnezzar's divinely sent dream, the Babylonian idols of the Regensburg, Munich, and New York World Chronicles divulge their fabricated and debased nature. Such images may not have inspired a revolution, but they could voice or nurture resistance to imagecentred devotion in more reserved terms.

\section{Echoes}

The artist behind the illumination in the Munich manuscript with which I opened this article depicted courtiers dressed in the height of contemporary fashion, on bended knee before an elevated finial (see plate 1). This presentation of idolatry at the ancient Babylonian court in a contemporary guise appears to index disdain for the central position of sculpture and ornament in the celebration of Christianity in the mid-fourteenth century. The Munich image serves as my smoking gun, a demonstration of the possibility of dissent against the dominant society being conveyed even in precious objects prized by the well-to-do. In images of Nebuchadnezzar's dream and idol in the other two manuscripts under consideration here, the Regensburg and New York codices, alternative iconographic elements bind the court of ancient Babylon to the late medieval milieu, suggesting scorn for presentday religious celebration, if in more muted tones.

With these works I aim to encourage art historians to listen for silences in and around the artworks we investigate. The connection between Weltchronik illuminations and heretical testimony is indirect. But even the most positivistic of minds can recognize that traditional histories - and art histories - are narratives pieced together from surviving sources to explain and often justify the triumphs of the powerful, while voices of the defeated are suppressed. Often these defeated voices are only faintly perceptible at all, to be discerned through a 'repositioning of the evidence' or inferred from scraps of testimony excluded from the rich archive of the victorious. ${ }^{66}$ 
Imagining the mental and physical terrain of reader-viewers, considering the ways in which images in manuscripts play upon the texts they accompany, straining to consider choices made by artists in anticipation of audience response - these interpretative modes might give us a chance as art historians to discern a faint utterance of dissent enunciated in an object of study. We might then turn up the volume, amplifying a perceived expression of resistance from a whisper to a scream. ${ }^{67}$

\begin{abstract}
Notes
I am grateful to many colleagues and friends for guidance and support as I wrote this article. Special thanks are due to: Kirk Ambrose, Eliza Garrison, Sandra Hindman, Katie Little, Elizabeth Morrison, Barbara Mundy, Libby Parker, Stephen Perkinson, Maria Ruvoldt, Kathryn Smith, and Karl Whittington. Michael Curschmann, Graeme Dunphy, and Susanne Hafner were particularly helpful, checking and correcting translations from Middle High German. And I especially appreciate the encouragement offered by Art History Editors Genevieve Warwick and Natalie Adamson and the critiques and comments from anonymous readers for the journal. Research for this article was supported by a Faculty Research Grant from Fordham University. I dedicate this piece to Glenn Hendler, who challenges and inspires me, and whose support, enthusiasm, and insight have been crucial to the development of this project.
\end{abstract}

1 Jörn-Uwe Günther, Die illustrierten mittelhochdeutschen Weltchronikhandschriften in Versen: Katalog der Handschriften und Einordnung der Illustrationen in die Bildüberlieferung, Munich, 1993 (no. 25), 209-19; and Handschriftencensus, Marburger Repertorium: http://www. handschriftencensus.de/7989 (accessed 27 May 2016); fully digitized at: http://daten.digitale-sammlungen.de/ db/0007/bsb00079954/ images/ (accessed 27 May 2016).

2 Uwe Neddermeyer, Von der Handschrift zum gedruckten Buch: Schriftlichkeit und Leseinteresse im Mittelalter und in der frühen Neuzeit - Quantitative und qualitative Aspekte, 2 vols. Buchwissenschaftliche Beiträge aus dem deutschen Bucharchiv München 61, Wiesbaden, 1998, 1: 269 and passim.

3 On the modernity of the gothic, see Marvin Trachtenberg, 'Suger's miracles, Branner's Bourges: Reflections on "Gothic architecture" as medieval modernism', Gesta, 39: 2, 2000, 183-205.

4 High profile examples are Jeffrey Hamburger, The Visual and the Visionary: Art and Female Spirituality in Late Medieval Germany, New York, 1998; Bonn, Kunst- und Austellungshalle der Bundesrepublik Deutschland, ed., Krone und Schleier: Kunst aus mittelalterlichen Frauenklöstern, Munich, 2005; Caroline Walker Bynum, Wonderful Blood: Theology and Practice in Late Medieval Northern Germany and Beyond, Philadelphia, PA, 2007; Caroline Walker Bynum, Christian Materiality: An Essay on Religion in Late Medieval Europe, New York, 2011; and Jacqueline Jung, 'The tactile and the visionary: Notes on the place of sculpture in the medieval religious imagination', in Colum Hourihane, ed., Looking Beyond: Visions, Dreams, and Insights in Medieval Art and History, Princeton, NJ, 2010, 203-40.

5 Günther, Die illustrierten mittelhochdeutschen Weltchronikhandschriften (no. 40), 315-23; and Handschriftencensus, Marburger Repertorium: http://www. handschriftencensus.de/14914 (accessed 27 May 2016).

6 Günther, Die illustrierten mittelhochdeutschen Weltchronikhandschriften (no. 36), 285-93; and Handschriftencensus, Marburger Repertorium: http://www. handschriftencensus.de/3936 (accessed 27 May 2016)

7 Günther, Die illustrierten mittelhochdeutschen Weltchronikhandschriften, 43-50.

8 Günther, Die illustrierten mittelhochdeutschen Weltchronikhandschriften, 43 and 51-61.

9 By date these are: Pommersfelden: Graf von Schönborn'sche Schloßbibliothek, cod. 303 (Bavaria-Austria, c. 1330-60); Stuttgart: Württembergische Landesbibliothek, cod. HB XIII 6 (BavariaAustria, c. 1340-50); Berlin: Staatsbibliothek, Ms. 389 (BavariaAustria, c. 1360-1400); Regensburg: Fürst Thurn und TaxisHofbibliothek, Ms. Perg. III (Bavaria, c. 1360); Munich: Bayerische Staatsbibliothek, Cgm 5 (Bavaria-Austria, c. 1370); Vienna: Österreichische Nationalbibliothek, cod. 2921 (Bavaria-Austria,
1397/98); Augsburg: Universitätsbibliothek, Cod. I.3.2 II (BavariaAustria, before 1400); New York: New York Public Library, Spencer Ms. 38 (Bavaria, 1402); Heidelberg: Universitätsbibliothek, Cpg 336 (Bavaria, c. 1410); Los Angeles, CA: J. Paul Getty Museum, Ms. 33 (Bavaria, c. 1400-10); Munich: Bayerische Staatsbibliothek, Cgm 250 (Bavaria, first half of fifteenth century). There are eight further Weltchronik manuscripts with a truncated version of the Daniel story, part of a divergent textual family associated with Heinrich von München (see note 13).

10 These manuscripts are analysed and catalogued in Günther, Die illustrierten mittelhochdeutschen Weltchronikhandschriften.

11 On this name, see Graeme Dunphy, 'Jans Enkel oder Jans von Wien?', Perspicuitas, 2003 (online). In the second half of the twentieth century, the convention was to call the author Jans Enikel. Now scholars find it more precise to refer to him as either Jans der Enikel (as advocated by Dunphy) or Jans von Wien (as in a recent study, Gesine Mierke, Riskante Ordnungen: Von der Kaiserchronik zu Jans von Wien, Deutsche Literatur, Studien und Quellen 18, Berlin, 2014, and in the online inventory of German medieval manuscripts Handschriftencensus, Marburger Repertorium). I opt for Dunphy's preferred nomenclature.

12 The available edition of the text is Philipp Strauch, Jansen Enikels Werke, MGH deutsche Chroniken, 3, Hanover and Leipzig 1891-1900; reprint, Munich, 1980; transcribed by Graeme Dunphy and Angus Graham and available online at http://www.dunphy.de/ac/je/ jehome.htm and also at http://www.hs-augsburg.de/ harsch/ germanica/Chronologie/13Jh/JansEnikel/jan_w000.html (both accessed 27 May 2016). Useful analysis of some portions is found in Raymond Graeme Dunphy, Daz was ein michel Wunder: The Presentation of Old Testament Material in Jans Enikel's Weltchronik, Göppingen, 1998.

13 A fourth Weltchronik author is Heinrich von München, but his text on Daniel is condensed and illuminated versions of it follow a divergent iconographic path from the one considered here. On Heinrich von München, see Horst Brunner, Johannes Rettelbach and Dorothea Klein, Studien zur 'Weltchronik' Heinrichs von München, 3 vols, Wiesbaden, 1998; and Norbert H. Ott, 'Heinrich von München', in Kurt Ruh, ed., Die deutsche Literatur des Mittelalters - Verfasserlexikon, Berlin, 1981, 3: 827-37.

14 Heinrich Jerchel, 'Die bayerische Buchmalerei des 14. Jahrhunderts', Münchner Jahrbuch der bildenden Kunst, n. F. 10, 1933, 70-109; Heinrich Jerchel, 'Beiträge zur österreichischen Handschriftenillustration', Zeitschrift des deutschen Vereins für Kunstwissenschaft, 2, 1935, 308-21; Norbert H. Ott, 'Typen der Weltchronik-Ikonographie: Bemerkungen zu Illustration, Anspruch und Gebrauchssituation volksprachlicher Chronistik aus überlieferungsgeschichtlicher Sicht', in Hans-Dieter Mück and Ulrich Müller, eds, Jahrbuch der Oswald von Wolkenstein Gesellschaft, 1, 1980/81, 29-55; Edmund Theil, commentary, Weltchronik, Rudolf von Ems - Karl der Große, der Stricker, Bozen, 1986; Ellen Judith Beer, Rudolf von Ems - Weltchronik, der Stricker - Karl der Grosse - Kommentar zu Ms. 302 Vad., Lucerne, 1987; and Martin Roland, 'Illustrierte Weltchroniken bis in die zweite Hälfte des 14. Jahrhundert', PhD dissertation, Vienna, 1991.

15 Günther, Die illustrierten mittelhochdeutschen Weltchronikhandschriften. An earlier study, addressing manuscripts containing only the text of Rudolf von Ems, is Christine Kratzert, 'Die illustrierten Handschriften der Weltchronik des Rudolf von Ems', PhD dissertation, Berlin, 1974.

16 Verena Kessel, 'Die Süddeutschen Weltchroniken der Mitte des 14. Jahrhunderts: Studien zur Kunstgeschichte in der Zeit der großen Pest', PhD dissertation, Bamberg, 1984; and Alison Beringer, 'The pictorial difference: The Old Testament Joseph cycle in two related manuscripts', Manuscripta, 53: 2, 2009, 153-77. See also Julia C. Walworth, Parallel Narratives: Function and Form in the Munich Illustrated 
Manuscripts of Tristan and Willehalm von Orlens, King's College London Medieval Studies 20, London, 2007.

17 It is worth noting that a recent study of Jans der Enikel's text, Mierke, Riskante Ordnungen, does include images from illuminated World Chronicle manuscripts, primarily from the manuscript in Regensburg considered in this article. But Mierke's focus is literary and she does not examine the images in iconographic, stylistic, or material terms

18 Michael Camille, The Gothic Idol: Ideology and Image-Making in Medieval Art, Cambridge, 1989, 219 and passim.

19 Beate Fricke, Fallen Idols - Risen Saints: Sainte Foy of Conques and the Revival of Monumental Sculpture in Medieval Art, trans. Andrew Griebeler, Turnhout, 2015.

20 Amy Knight Powell, Depositions: Scenes from the Late Medieval Church and the Modern Museum, New York, 2012, 24-5.

21 Powell, Depositions, 10, 46, and passim.

22 Powell, Depositions, 26-9.

23 The text on fol. $165 \mathrm{v}$ reads in part: Item in dem $L V$ iar hat ich hans puczner die selb czeit lanttschreiber czu purchhausen an den obristen geoppfert xxxiiij d (Pfennige). For the full text, see Günther, Die illustrierten mittelhochdeutschen Weltchronikhandschriften, 316-17.

24 The related manuscript is Linz: Oberösterreichische Landesbibliothek, Ms. 472; Günther, Die illustrierten mittelhochdeutschen Weltchronikhandschriften (no. 22), 183-93.

25 Liselotte Constanze Eisenbart, Kleiderordnungen der deutschen Städte zwischen 1350 und 1700: Ein Beitrag zur Kulturgeschichte des deutschen Bürgertums, Göttingen, 1962, 155.

26 It should be noted that in some illuminated World Chronicles, Kruseler are found on women who are not to be seen as treacherous, and in these cases the ruffles seem to function simply as more or less neutral injections of contemporary fashion into images of the past. For instance, in New York, Morgan Library, Ms. M. 769 (Regensburg, c. 1360) female figures including Jael (fol. 139r) and Susanna (fol. 237v) wear the frilled ornament. I thank an anonymous reader for this observation.

27 See Kessel, 'Die Süddeutschen Weltchroniken', 83-90.

28 Discussed in Assaf Pinkus, Sculpting Simulacra in Medieval Germany, 1250-1380, Aldershot, 2015, 105-10.

29 There are also many Ursula Bust figures from Cologne that sport Kruseler. For instance, see Ulrike Bergmann, ed., Schnütgen Museum: Die Holzskulpturen des Mittelalters (1000-1400), Cologne, 1989 (no. 88), 314-16. I thank an anonymous reader for this reference.

30 'Es sol och kain wip noch frow, dú burgerin ist, kain sidin tūch uf ir hobet tragen úber zwaintzig vach und wer daz úberwert, der mūs geben den burgern ain pfunt pfennig ...' Karl Otto Müller, ed., in Oberschwäbische Stadtrechte, vol. 2, Die älteren Stadtrechte der Reichsstadt Ravensburg, Württembergische Geschichtsquellen 21, Stuttgart, 1924, 173. On the dating and other particulars of the manuscript from which this comes, see Müller, Oberschwäbische Stadtrechte, 2: 25-32.

31 For introductions to secular life in Regensburg in the high and late Middle Ages, see essays in Martin Angerer and Heinrich Wanderwitz, eds, Regensburg im Mittelalter: Beiträge zur Stadtgeschichte vom frühen Mittelalter bis zum Beginn der Neuzeit, Regensburg, 1995; and Peter Morsbach, ed., Regensburg: Metropole im Mittelalter, Regensburg, 2007, 186-243.

32 Richard Strobel, Das Bürgerhaus in Regensburg - Mittelalter, Tübingen, 1976, $62,99,106,108,109$, and 327-8.

33 Strobel, Das Bürgerhaus in Regensburg, 181-2, and 189.

34 Achim Hubel and Manfred Schuller, Der Regensburger Dom, Regensburg, 2008.

35 Horst Bredekamp, Kunst als Medium sozialer Konflikte: Bilderkämpfe von der Spätantike bis zur Hussitenrevolution, Frankfurt am Main, 1975, 11-13, 330-3, and passim.

36 The scholarship on Waldensians is extensive. For an introduction to issues and bibliography, see Euan Cameron, Waldenses: Rejections of Holy Church in Medieval Europe, Oxford, 2000.

37 Johann Joseph Ignaz von Döllinger, Beiträge zur Sektengeschichte des Mittelalters, 2 vols, Munich, 1890; rpt. New York, 1960, 2: 305-15, at 307.

38 Classic studies of German Waldensians are: Herman Haupt, Waldenserthum und Inquisition im südöstlichen Deutschland, Freiburg, 1890; Alexander Patschovsky, Der Passauer Anonymus: Ein Sammelwerk über Ketzer, Juden, Antichrist aus der Mitte des 13. Jahrhunderts, Schriften der MGH,
Deutsches Institut für Erforschung des Mittelalters, 22, Stuttgart, 1968; Richard Kieckhefer, The Repression of Heresy in Medieval Germany, Philadelphia, PA, 1979, chapter 4; Martin Schneider, Europäisches Waldensertum im 13. und 14. Jahrhundert: Gemeinschaftsform, Frömmigkeit, sozialer Hintergrund, Berlin, 1981, 95-130.

39 For lists of the cities, Margaret Anne Eugenie Nickson, 'The "PseudoReinerius" treatise, the final stage of a thirteenth-century work on heresy from the Diocese of Passau', Archives d'histoire doctrinale et littéraire du Moyen-Age, 34, 1967, 255-314, at 278-80, 294-5, 308-9 and 314. See also Peter Segl, Ketzer in Österreich: Untersuchungen über Häresie und Inquisition im Herzogtum Österreich im 13. und beginnenden 14. Jahrhundert, Quellen und Forschungen aus dem Gebiet der Geschichte n. F. 5, Paderborn, 1984, chapter 2

40 Peter Biller, 'German money and medieval heresy: The wealth of the German Waldensians', in The Waldenses, 1170-1530: Between a Religious Order and a Church, Aldershot, 2001, 111-23; for the high-ranking urbanites pertinent to this study 113-19. See also Schneider, Europäisches Waldensertum, 114-20.

41 I am aware that confessions of heretical belief could be coerced and that on those grounds some scholars discredit their value for understanding popular belief (see for instance, Bynum, Christian Materiality, 163-5), but the critical mass of evidence convinces me that inquisitor texts index a real resistance to image-centred devotion.

42 Peter Zwicker, Cum dormirent homines is available (and misattributed to Peter of Pilichdorf) in an edition by Jacob Gretser, reproduced in Maxima bibliotheca veterum patrum, ed. Margarino de la Bigne, 28 vols, Lyons, 1677-1707, 25:277G-299E, here 281E. Peter Biller, 'The antiWaldensian treatise Cum dormirent homines of 1395 and its author', in The Waldenses, 237-69; and Peter Biller, 'Waldensians in German-speaking areas in the later fourteenth century: The view of an inquisitor', in The Waldenses, 271-91. On Zwicker, also see Haupt, Waldenserthum, 84-93.

43 Georg Modestin, 'The anti-Waldensian treatise Cum dormirent homines: historical context, polemical strategy, and manuscript tradition', in Michael Van Dussen and Pavel Soukup, eds, Religious Controversy in Europe, 1378-1536: Textual Transmission and Networks of Readership, Turnhout, 2013, 211-29, at 223.

44 Heinrich Finke, 'Waldenserprocess in Regensburg 1395', Deutsche Zeitschrift für Geschichtswissenschaft, 4: 2, 1890, 345-6; and Kiekhefer, Repression of Heresy, 54, 66, 131-2, nn. 8 and 11; as well as Haupt, Waldenserthum, 3: 336-49.

45 Quoted with full citation in Norbert Schnitzler, IkonoklasmusBildersturm: Theologischer Bilderstreit und ikonoklastisches Handeln während des 15. und 16. Jahrhunderts, Munich, 1996, 54-5, n. 94.

46 Indeed, Zwicker's catalogue of Waldensian critiques of pious practices reads like a synopsis of the late medieval Christian devotional acts often celebrated in today's art-historical scholarship. For anti-heretical tracts as evidence of lay practices, see Peter Segl, 'Spätmittelalterliche Volksfrömmigkeit im Spiegel von Antiketzertraktaten und Inquisitionsakten des 13. und 14. Jahrhundert', in Peter Dinzelbacher and Dieter R. Bauer, eds, Volksreligion im hohen und späten Mittelalter, Paderborn, 1990, 163-76; and Pavel Kalina, 'Cordium penetrativa: An essay on iconoclasm and image worship around the year 1400', Umění, 43: 1-2, 1995, 247-57. On sculpted images of Christ crucified with moveable arms, see Gesine Taubert and Johannes Taubert, 'Mittelalterliche Kruzifixe mit schwenkbaren Armen: Ein Beitrag zur Verwendung von Bildwerken in der Liturgie', Zeitschrift des deutschen Vereins für Kunstwissenschaft, 23, 1969, 79-121; Johannes Tripps, Das handelnde Bildwerk in der Gotik: Forschungen zu den Bedeutungsschichten und der Funktion des Kirchengebäudes und seiner Ausstattung in der Hoch- und Spätgotik, Berlin, 1998, 121-8; Joseph Koerner, 'The icon as iconoclash', in Iconoclash: Beyond the Image Wars in Science, Religion, and Art, Cambridge, MA, 2002, 164-213, at 191-2; Kamil Kopania, Animated Sculptures of the Crucified Christ in the Religious Culture of the Latin Middle Ages, Warsaw, 2010, 120-46; and Powell, Depositions, 45-57 and 81-90. I thank Amy Knight Powell for help with references.

47 Zwicker, Cum dormirent homines, chapter 33, 296-97, at 297B; Biller, 'Waldensians in German-Speaking Areas', 289.

48 Zwicker, Cum dormirent homines, chapter 27, 292-3, at 293D

49 Nickson, 'Pseudo-Reinerius', 312, quoting the transcript of a 1315 inquisition in Krems. On dating, see 277, 303, and 311.

50 One example among many dates from a 1392 interrogation: 
'Interrogata, an asperserit se aqua benedicta et crediderit aliquid valere, respondit, sic et fecerit, ne notaretur'. Dietrich Kurze, Quellen zur Ketzergeschichte Brandenburgs und Pommerns, Berlin, 1975, 86 (no. 13, pt. 16); and see also 92 (no. 17, pt. 14), 157 (no. 91, pt. 16), 160 (no. 94, pt. 16), 173 (no. 106, pt. 16), 210 (no. 145, pt. 16).

51 Nickson, 'Pseudo-Reinerius', 312-13, from a 1315 inquisition (see note 49). See also Kurze, Quellen zur Ketzergeschichte, 156 (no. 90, pt. 16), 165 (no. 99, pt. 14), 198 (no. 136, pt. 16), 199 (no. 137, pt. 16), 201 (no. 139, pt. 16), 206 (no. 142, pt. 16), 208 (no. 144, pt. 16), 212 (no. 148, pt. 16) 258 (no. 193, pt. 16).

52 See Kieckhefer, Repression of Heresy, 55; and Cameron, Waldenses, 139-44.

53 Karl Ubl, 'Die Verbrennung Johannes Grießers am 9. September 1411: Zur Entstehung eines Klimas der Verfolgung im spätmittelalterlichen Österreich', Mitteilungen des Instituts für österreichische Geschichtsforschung, 119: 1-2, 2011, 60-90, at 76, citing Döllinger, Beiträge, 2: 343-4.

54 Ubl, 'Die Verbrennung', 78-9.

55 Addressed in my article 'Biblical history comes home: Daniel and Nebuchadnezzar in late medieval illuminated Weltchroniken', Gesta 57:1, Spring 2018.

56 Matthias Lexer, Mittelhochdeutsches Handwörterbuch, vol. 1, Leipzig, 1872, available online: http://woerterbuchnetz.de/Lexer/ (accessed 27 May 2016).

57 I am grateful to Nancy Turner, Conservator of Manuscripts, the J. Paul Getty Museum, who assessed this image based on a photograph of the detail (9 May 2013). Turner remarks that the iridescence of the image perhaps is due to impurities in the silver. I thank Elizabeth Morrison, Senior Curator and Department Head, Illuminated Manuscripts at the Getty, for facilitating this exchange.

58 Siul or a variant appears thirteen times in this episode of the Daniel story as told in Jans der Enikel's text (1l. 17211-17310): 11. 17218, 17228, 17230, 17235, 17241, 17246, 17248, 17253, 17255, 17263, 17277,17283 , and 17286 .

59 These standards are characterized in Camille, Gothic Idol, 66-7.

60 See Dunphy, Daz was ein michel Wunder, 241-3. These and many other terms for contemporary instruments are analysed in Astrid Eitschberger, Musikinstrumente in höfischen Romanen des deutschen Mittelalters, Wiesbaden, 1999. I thank Eric Bianchi for this reference.

61 I explore this motif in my article, 'Biblical history comes home', cited in note 55 .

62 See the references in notes 48 and 51.

63 I owe my understanding of these lines to Susanne Hafner.

64 On Hussite iconoclasm, see Bredekamp, Kunst als Medium, 271-6 and 297-302; for claims of the devil residing in devotional images, 254-5.

65 For an overview of the complicated history of this and related images, see Hans Belting, Likeness and Presence: A History of the Image before the Era of Art, trans. Edmund Jephcott, Chicago, IL, 1994, 453-7.

66 See Michel-Rolph Trouillot, Silencing the Past: Power and the Production of History, Boston, MA, 1995, 25-9, quote at 27. On the interpretative process and the search for historical truth, see Tzvetan Todorov, The Morals of History, trans. Alyson Waters, Minneapolis, MN, 1995, 87-125.

67 Copyright, Declan MacManus, 1981. 